\title{
How Taxes and Required \\ Retums Drove Commercial \\ Real Estate Valuations over the Past Four Decades
}

J ohn V. Duca, Patric H. Hendershott and David C. Ling

Federal Reserve Bank of Dallas

Research Department

Working Paper 1703 


\title{
How Taxes and Required Returns Drove Commercial Real Estate Valuations over the Past Four Decades*
}

\author{
John V. Duca \\ Research Department, Federal Reserve Bank of Dallas and Southern Methodist University: \\ john.v.duca@dal.frb.org \\ Patric H. Hendershott University of Aberdeen Business School, Scotland: \\ phh3939@gmail.com \\ David C. Ling \\ McGurn Professor of Real Estate, Hough Graduate School of Business, University of Florida: \\ ling@ufl.edu
}

Earlier versions were presented at the Annual National AREUEA Conference in Washington on June 3, 2016, the AREUEA-ASSA Annual Conference in Chicago on January 6, 2017 and the American Real Estate Society annual conference in Denver on March 31, 2016.

May 15, 2016

Revised, January 27, 2017

\begin{abstract}
$\underline{\text { Abstract }}$
We document the evolution of U.S. tax law regarding commercial real estate (CRE) since 1975, noting changes in income and capital gains tax rates and tax depreciation methods. The most prominent changes were the 1981 and 1986 Tax Acts, but numerous significant changes occurred in the last dozen years. We then compute the present value of tax depreciation per dollar of acquisition price and an effective tax rate for CRE. We explain the quarterly variation in CRE capitalization rates using an error correction framework and find that the long run estimates are statistically significant in the way theory would suggest. Moreover, the required financial asset return and the tax depreciation variable temporally predict ("cause") capitalization rates in the long run, but not vice versa.
\end{abstract}

JEL codes: H20, H30, G12, R30

*Hendershott and Ling gratefully acknowledge funding for this research provided by REALTOR University through the Richard J. Rosenthal Center for Real Estate Studies. We thank the American Council of Life Insures for providing data for this project and Matt Wellens of the American Council of Life Insurers for support. For helpful comments and suggestions, we thank Jesse Boyles, Jim Follain, David Geltner, William Gentry, Eva Steiner, two anonymous referees, and session participants at the 2016 ARES, 2016 National AREUEA, and 2017 AREUEA-ASSA conferences. We also thank Camden Cornwell and Amirhossein Yousefi for excellent research assistance. The views expressed are those of the authors and do not necessarily reflect those of the Federal Reserve Bank of Dallas or the Federal Reserve System. 


\section{INTRODUCTION}

Although commercial real estate (CRE) is a small sector-accounting for 2.8 percent of U.S. GDP, the damage to the banking system associated with past collapses in CRE prices and loan quality has played a notable role in deepening two of the last three recessions. For example, the CRE boom of the 1980s and the subsequent bust led to loan losses that induced a broad credit crunch that helped push the U.S. economy into recession in 1990 (see Bernanke and Lown, 1991, and Browne and Case, 1992). These effects were exacerbated by an illadvised easing of regulations in the early 1980s on insolvent thrift institutions that expanded into CRE lending (see Hendershott and Kane, 1992). More recently, loan losses on commercial mortgages and construction and land development loans played a very large — if not a leading role-in triggering bank failures in the Great Recession (Antoniades, 2014) and in inducing a credit crunch that deepened and prolonged the downturn (Duca and Muellbauer, 2014).

A key driver of swings in CRE prices and activity is the required return to investors. This return depends on many factors. First is how real estate is expected to perform economically. Second is how property returns are taxed, which includes how returns are measured (what expenses are deductible) and what tax rates are applied. The taxation of returns has varied greatly over the last forty years, as has expected economic performance. A third factor is how alternative investments are taxed and expected to perform.

Scarce capital resources are allocated across sectors based on expected after-tax rates of return and risk (Bailey, 1974). Capital moves between sectors and relative nominal prices adjust until real, risk-adjusted after-tax yields are the same at the margin for all capital goods.

This paper begins by documenting the legislated changes in CRE taxation during the 1975-2015 period. We conclude this discussion with the calculation of the present value of tax depreciation allowances per dollar of acquisition price. In contrast to tax rates that apply to most assets, including bond yields that are often used to track before-tax required rates of return, tax depreciation allowances for structures are available to few assets. Consequently, 
the value of CRE tax depreciation provisions likely contains information relevant to the determination of capitalization rates (income to price ratios) and CRE valuations.

We then calculate the effective tax rate on CRE as the difference between the beforeand after-tax expected internal rates of return (IRRs) on CRE divided by the before-tax IRR. The most important determinant, beyond the general tax rate applied to the net returns and the depreciation deductions allowed, is the measurement and taxation of capital gains. Lastly we estimate an error correction model to illustrate how expected real financial asset returns and the value of tax depreciation allowances affected CRE capitalization rates, and thus CRE asset prices, over the last four decades.

\section{THE HISTORIC TAXATION OF CRE}

Income-producing real estate has received widespread attention as a tax shelter. Like most income producing assets, annual cash inflows net of deductible expenses are taxed. In addition to operating expenses, the periodic interest investors pay for borrowing is generally deductible in the year in which it is paid. Moreover, the allowable annual depreciation deduction is unaffected by the mix of debt and equity financing because the entire acquisition cost (minus the value of the land) is depreciable. Thus, increased leverage magnifies the ratio of allowable depreciation deduction relative to the required equity investment.

Our paper classifies equity investments in income-producing property as "trade or business" properties (under IRC Section 1231), which are permitted a deduction (“allowance”). ${ }^{1}$ Because CRE depreciates as the property ages, a depreciation deduction against the rental income generated by the property is reasonable. ${ }^{2}$ While tax rates on trade or business income and capital gain income vary by state, allowable deductions are usually calculated in a manner similar to federal law. ${ }^{3}$ Our analysis focuses on the federal taxation of real property.

\footnotetext{
${ }^{1}$ Real estate held as a personal residence and real estate held for sale (“dealer” property) cannot be depreciated.

2 Estimating true economic depreciation for investment real estate has proven challenging. See, for example, Hulten and Wykoff (1996), and Bokhari and Geltner (2016).

3 The present value of depreciation deductions will be higher in states with high marginal rates of taxation.
} 
The size of the annual depreciation deduction is prescribed by federal law and depends on three factors: the amount of the depreciable basis, the cost recovery period, and the method of depreciation. The depreciable basis for existing CRE assets equals the total acquisition price of the property, including expenses directly associated with acquiring the property, minus the estimated value of the land. 4 The minimum cost recovery period over which real property may be depreciated and the allowable method of depreciation has frequently been changed by Congress. In 2016, residential income producing property (e.g., apartments) may be depreciated over 27.5 years using straight-line depreciation; for nonresidential real property (e.g., shopping centers, office buildings, warehouses, etc.) the period is 39 years. ${ }^{5}$ The latter imples an annual deduction of 2.564 percent (1/39) of the depreciable real property basis. ${ }^{6}$

Our study covers 1975 Q1 to 2015Q4. Before the 1981 Economic Recovery Tax Act (ERTA), allowable cost recovery periods for real property were based on the concept of useful life (Robinson, 1984; pp. 6-14). Generally, the IRS allows a 30 year tax life for used CRE and requires straight-line depreciation for non-residential property. Accelerated methods of depreciation were allowed for new residential (200\% declining-balance), used residential (125\% declining balance), and new non-residential properties (150\% declining balance).

ERTA accelerated depreciation allowances. Both residential and nonresidential real property purchased after 1980 could be depreciated over 15 years using $175 \%$ declining balance depreciation. This implied a first-year depreciation deduction equal to 11.67 percent $[1.75 \mathrm{x}$ (1/15)] of the depreciable real property basis. For property put in service after March 15, 1984 and before May 9, 1985, the Tax Reform Act of 1984 increased the minimum cost recovery

\footnotetext{
${ }^{4}$ For existing properties, IRC Section 1060 specifies how total acquisition costs are allocated between land and property, and allows the basis to be allocated based on the relative fair market values of the nondepreciable land and depreciable improvements (Manolaksa and Anderson, 1990, p. 76). Another complication is that the depreciable basis may be further segregated into real property and personal property. Personal property can usually be depreciated for tax purposes at a faster rate than real property.

5 An income-producing real property is considered a "residential" property for income tax purposes if at least 80 percent of the property's gross rental income is derived from the leasing of non-transient dwelling units.

${ }^{6}$ Regardless of the date of purchase, current law assumes the property is placed in service on the $15^{\text {th }}$ day of the month of acquisition. Thus, if a property is purchased on January 10, the depreciation rate applied to the depreciable basis of the real property is $0.03485=(11.5$ months $\div 12$ months $) \times(1 / 27.5)$. The IRS provides details.
} 
period for both new and used residential and nonresidential real property from 15 to 18 years. For property placed in service after May 8, 1985 and before the end of 1986, the minimum cost recovery period for residential and non-residential real property was extended to 19 years.

The Tax Reform Act of 1986 eliminated accelerated depreciation for most real property. The cost recovery period for acquisitions of new and used residential property placed in service after 1986 was increased to 27.5 years, while that for nonresidential property was lengthed to 31.5 years. The Omnibus Budget Reconciliation Act of 1993 further extended the cost recovery period for nonresidential real property to 39 years. Cost recovery periods and allowable methods of depreciation over our study period are summarized in the top part of Table 1 .

The annual depreciation deduction when accelerated depreciation is permitted is comprised of two parts: the straight-line portion $\left(S L D E P_{t}\right)$ and the "excess" portion that results from the use of accelerated depreciation $\left(E X D E P_{t}\right)$. Both of these can be written off without limit against positive taxable income generated by other Section 1231 (trade or business) assets. We denote this tax rate by $\tau$ ттвI.

The second four rows in Table 1 contain relevant tax rates. During the early years of our sample, the maximum statutory federal rate applicable to taxable income generated by Section 1231 trade or business assets, or other investment income, was 70 percent. ERTA 1981 reduced the maximum federal tax rate on trade or business income to 50 percent. TRA 1986 reduced this rate to 28 percent, although this reduction was phased in over one year. ${ }^{7}$ This marked a 60 percent reduction in the top marginal rate from 70 percent in 1980 . Before TRA 1986, if the netting of positive and negative taxable income on all of the taxpayer's trade or business assets produced negative taxable income, these "extra" tax losses could be used to directly offset earned (wage and salary) income. Since 1986, these extra deductions have had

\footnotetext{
${ }^{7}$ A maximum tax rate of 38.5 percent applied to trade or business income in 1987, dropping to 28 percent in 1988. In 1988-90, a 33 percent "rate bubble" applied to taxable income between $\$ 71,900$ and $\$ 149,250$ for married couples filing jointly to recapture taxes upper-income taxpayers saved by using the lower 15 percent rate.
} 
to be carried forward and used in subsequent years to the extent that sufficient net taxable income is produced by the operation or sale of the taxpayer's trade or business assets. ${ }^{8}$

The maximum rate on trade or business income was raised to 31 percent, effective in 1991 and 1992, and to 39.6 percent in 1993 . This rate persisted through 2000 , after which it was gradually reduced to 35 percent in 2003, where it remained through 2012 . The American Taxpayer Relief Act of 2012 increased the maximum statutory rate to $39.6 \% .^{9}$ This Act also introduced a Net Investment Income Tax (NIIT) surcharge under I.R.C. Section 1411 of 3.8 percent that applies to married households with modified adjusted gross income (AGI) in excess of $\$ 250,000$, effectively raising the maximum rate to 43.4 percent $(39.6 \%+3.8 \%) .{ }^{10}$

The appropriate tax treatment of capital gains is complicated. Under a pure net accretion (Haig-Simons) approach to income taxes, real capital gains are taxed each year as they accrue and real capital losses are deducted. The taxation of nominal capital gains at disposition creates a potential "lock-in" effect. Rather than selling a suboptimal asset with a lower expected before-tax return and reinvesting the proceeds in a higher expected return asset, investors with accrued capital gains may continue holding the less productive asset to avoid incurring taxable gains. ${ }^{11}$ This suboptimal allocation of scarce investment capital exacts a cost on the economy as well as on the taxpayer. If nominal gains are to be taxed, the optimal taxation of deferred capital gains should vary with inflation; in particular, high inflation

\footnotetext{
8 The inability since TRA 1986 of taxpayers to fully use net tax losses from trade or business assets to offset "ordinary" wage and salary income or portfolio income is known as passive activity loss restrictions. See IRS publication 925, Form 8582 and Follain, Hendershott, and Ling (1987). All income generated by rental real estate is classified as trade or business income and, in Form 8582, as "passive" income.

${ }_{9}^{9}$ Since the passage of TRA 1986, the ability of higher income households to benefit fully from Schedule A (itemized) deductions and personal exemptions has been curtailed. This raises effective marginal tax rates. For details, see IRS Publication 17, Section 29, pp. 202-203 (itemized deductions) and p. 38 (personal exemptions).

10 The NIIT surtax of 3.8 percent is imposed on the lesser of: (1) net investment income and (2) the excess of the taxpayer's modified AGI over $\$ 250,000$ (joint filers), $\$ 200,000$ (single filers) or $\$ 125,000$ (married couples filing jointly). If a taxpayer is in the 35 percent or 39.6 percent bracket on ordinary and trade or business income, they are subject to the surtax. For details, see: http://taxfoundation.org/article/federal-capital-gains-tax-rates-19882013. "Real estate professionals" who spend substantial time working (more than 750 hours per year) in activities related to real estate, broadly defined, may avoid the 3.8 percent surtax.

${ }_{11}$ Papers analyzing lock-in effects in real estate markets include Sinai and Gyourko (2004), Ferreira (2010), and Ihlanfeldt (2011). The responses associated with capital gain tax rates are complex and empirical estimates of the responsiveness vary (e.g., Autin and Clotfeller (1982), Burman and Randolph (1994), and Gravelle (1994).
} 
should be accompanied by lower rates of capital gain taxation, all else equal. Feldstein and Slemrod (1979) make a case for low or zero, taxation of inflationary gains.

Depreciation deductions written off against the taxpayer's marginal tax rate on trade or business income produce annual tax savings. However, each dollar of depreciation reduces the investor's tax basis in the property by a dollar, thereby increasing the taxable gain on sale by a dollar. Cumulative straight-line deductions at the time of sale may be taxed at a different rate than cumulative excess deductions. Thus, the net present value of depreciation deductions, per dollar of acquisition price, over a $N$-year holding period equals:

$$
\text { taxdep }=\left(\sum_{t=1}^{N} \frac{\left(S L D E P_{t}+E X D E P_{t}\right) \tau_{T B I}}{(1+k)^{t}}-\frac{\left(\sum_{t=1}^{N} S L D E P_{t} \tau_{S L R}+\sum_{t=1}^{N} E X D E P_{t} \tau_{E X R}\right)}{(1+k)^{N}}\right) / P_{O}
$$

where $k$ is the appropriate after-tax discount rate, $\tau_{S L R}$ is the rate of tax applicable at sale to cumulative straight-line deductions and $\tau_{E X R}$ is the tax rate applicable to the sum of excess deductions over the $N$-year holding period. ${ }^{12}$

If $\tau_{S L R}$ and $\tau_{E X R}$ at sale equal $\tau_{T B I}$, the only benefit from annual depreciation deductions is a deferral benefit, amounting to a series of $N$ annual interest-free loans from the U.S. Treasury. This deferral benefit is increasing in the magnitude of the annual deductions, the length of the investment holding period, and the after-tax discount rate. However, if $\tau_{S L R}$ and/or $\tau_{E X R}$ are below $\tau_{T B I}$, as has been true since 1998, then the tax on depreciation recapture income at sale is less than sum of federal income taxes saved by annual depreciation deductions. Said differently, the effective interest rate on the annual "loans" from the Treasury is negative. Thus, in addition to deferring taxes to the year of sale with annual depreciation deductions, investors can convert some annual income that would have been taxed at their marginal tax rate on trade or business income into income taxed at a lower depreciation recapture rate.

\footnotetext{
12 For individuals and partnerships, tax losses from "passive" investment activities can be used to offset positive taxable income from other passive activities. However, net passive losses may not be used to offset wage and salary income or portfolio income (see IRS publication 925 and Form 8582). We assume throughout our analysis that passive activity loss restrictions, instituted by the Tax Reform Act of 1986, are not binding for the marginal CRE investor. To the extent such restrictions are binding, the effective rate at which depreciation is deducted may be lower than their marginal rate, which would decrease taxdep.
} 
Before 1962, all taxable gains on the sale of real property were taxed at capital gain tax rates. The first real property recapture rule (Section 1250 of the IRC) was applied in 1964 and was extended by the Tax Reform Act of 1969 to provide for unlimited depreciation recapture of excess depreciation at the taxpayer's marginal rate on trade or business income. However, the straight-line portion of the taxable gain was taxed at capital gain tax rates. ${ }^{13}$

Accelerated depreciation was not available with the acquisition of existing nonresidential properties from 1976 through 1980. Between 1981 and 1986 when accelerated depreciation was available, the excess over straight-line was taxed at a rate of $\tau_{\text {TBI. }}$

Our base-case calculations assume the marginal investor in CRE faces the maximum statutory federal tax rates on ordinary, capital gain and depreciation recapture income. In a seminal article on investment returns and U.S. income taxation, Bailey (1974) states:

"Because tax deductions and tax credits associated with particular investments are worth more in equivalent pretax income to a high-bracket taxpayer than to a lowbracket one, tax privileged investments find their way into the hands of high-bracket taxpayers. Their competition with each other and with the next lower brackets drive down pretax rates of return on such investments (p. 1157)."

This suggests that CRE assets are likely held by high-bracket taxpayers and that competitively determined pretax expected returns are driven by these taxpayers. In addition to being outbid by higher-bracket taxpayers for the tax shelter advantages of CRE assets, low-bracket taxpayers are unlikely to have enough wealth to invest in CRE investment vehicles.

Data from the 2014 IRS Statistics of Income (SOI) empirically support the widely-held assumption that real property investments are held primarily by high-bracket taxpayers. CRE can be owned directly (e.g., sole proprietorship) or with other investors in a partnership, limited liability company, S corporation, real estate investment trust, or other investment vehicle. The tax consequences of CRE ownership (in non-exchanged-traded securities) are

\footnotetext{
${ }^{13}$ See Manolakas and Anderson (1990, pp. 143-146) for details. Recapture of the excess of accelerated depreciation over straight-line was phased out by one percentage point per month after 100 months for rental housing not receiving public assistance and after 20 months for publically assisted rental housing. For rental housing held for 200 months, all depreciation could be converted to capital gain income.
} 
reported on Schedule E of Form 1040 under rents received from direct investments in individual properties (row 3) or income or loss from partnerships and S corporations (row 32).

Figure 1 shows the relation in 2014 between adjusted gross income (AGI) and the percentage of taxpayers reporting the receipt of rents from property investments. For taxpayers with AGI under $\$ 200,000$, the share of returns reporting rental income from property ranges from 1.2 to 6.7 percent (shaded bars). In contrast, 14.4 percent of taxpayers with AGI between $\$ 500,000$ and $\$ 1,000,000$ reported property rents, and this share exceeds 17 percent for taxpayers with AGI above $\$ 1,000,000$. The average rental income per return for households with AGI between $\$ 1,000,000$ and $\$ 10,000,000$ ranges from $\$ 79,136$ to $\$ 422,931$. Clearly, the majority of rents from CRE investments are reported by taxpayers in the highest marginal bracket. The share of taxpayers by AGI category reporting income from partnerships and $\mathrm{S}$ corporations in 2014 on Schedule E is also shown in Figure 1 (cross-hatched bars). ${ }^{14}$ Like the rental income data, the percentage is very low - one to eight - for households with income under $\$ 200,000$, but for households with AGI above $\$ 1,000,000$, the percentage is sixty.

The maximum statutory rate on capital gain income was 36.5 percent in 1975 and 39.875 percent from 1976 to 1978:Q2. 43 percent of gains were excluded from taxation in 1975 through 1978Q2 and 60 percent through 1987. The increase to 60 percent was part of the reduction in capital gains taxes featured in the 1978 Act (Penick, 1983). The maximum capital gains tax rate was reduced to 33.85 percent in the last half of 1978 and to 28 percent starting in the first quarter of 1979 . The 1981 ERTA cut the maximum capital gain tax rate to 20 percent in the third quarter of 1981, which remained in effect until 1987, when TRA 1986 raised this rate back to 28 percent. This maximum statutory rate was again cut to 20 percent in the second quarter of 1997 and to 15 percent in the second quarter of 2003, before being raised back to 20 percent in the first quarter of 2013. Moreover, for married households with

\footnotetext{
${ }^{14}$ This income includes that from non-real-estate investment activities.
} 
AGI above $\$ 250,000$, the maximum capital gain rate became 23.8 percent, the sum of the 20 percent maximum statutory capital gain tax rate and the 3.8 percent NIIT surtax.

From 1975 through 1997, the capital gain tax rate applied to the recapture of straightline depreciation at sale, allowing the conversion of unearned income into capital gain income. In 1998 a maximum depreciation recapture tax rate of 25 percent was introduced, remaining in effect since then. However, for married households with AGI above $\$ 250,000$ the maximum depreciation recapture rate since $2013 \mathrm{Q} 1$ equaled 28.8 percent, the sum of the 25 percent maximum statutory rate and the 3.8 percent NIIT surcharge.

Maximum federal tax rates on trade or business and capital gain income are shown in Figure 2. The income tax rate was cut from 70 to 28 percent during the Reagan years but has since risen to 43.4 percent. For most of the period the capital gains rate (including the exclusion) was about half the regular income tax rate. However, over 1987-96, the gains rate was relatively higher (the gains rate equaled the trade or business rate in 1989).

The amount of annual depreciation deductions depends on the proportion of the acquisition price that represents non-depreciable land. Land value as a share of total property value ("land share") varies over time, markets, and property types. Bokhari and Geltner (2016) find that land shares for newer residential income-producing property averaged about 20 percent from 2005 to 2015 . We assume this share in our base-case calculations of taxdep and effective tax rates for residential and nonresidential property. ${ }^{15}$

The net present value of depreciation deductions also varies with the investment holding period and the after-tax discount rate. The property is expected to be held for 10 years

\footnotetext{
15 On average, land is a larger component of property value in housing than in more developed commercial properties, implying a higher land share in residential markets. However, commercial properties are usually built on more expensive land than residential properties. Bokhari and Geltner (2016) estimate that land shares for relatively new nonresidential properties averaged about 30 percent from 2005 to 2015 . To better isolate the effects of differential taxation over time, we assume a 20 percent land share for both property types.
} 
before being disposed of in a fully taxable sale. A 10-year holding period assumption accords with both ex post empirical evidence and holding period expectations derived from surveys. ${ }^{16}$

If the acquired asset remains in service as a rental property and Congress does not retroactively alter allowable depreciation, the size of annual deductions and depreciation recapture income at sale are predictable. However, there is risk at acquisition that the property will not remain in continuous service or Congress may alter allowable deductions. In addition, the holding period at acquisition is uncertain, and the tax rate applicable to annual deprecations and recapture income in the year of sale may vary due to changes in taxpayer income or tax law. Although not risk free, depreciation tax savings over an assumed holding period are more certain than the residual cash flows to equity investors. We assume the pretax discount rate used to value depreciation tax savings is the after-tax rate on Baa-rated corporate bonds whose nominal yields ranged from 4.5 to 17.0 percent over our sample and averaged 9.0 percent. The tax rate used is the maximum tax rate on trade or business income.

Figure 3 plots this net present value as a percentage of the acquisition price, taxdep, for used property. In the late 1970s, this share ranged from eight to ten percent. In 1981 ERTA increased the percentage to about 23 by reducing the cost recovery period to 15 years and accelerating depreciation to 175 percent of straight line. However, the reduction in the maximum tax rate on trade or business income to 50 percent lowered the present value ${ }^{17}$ to approximately 15 percent in 1982 and 1983, and TRA 1986 slashed the value to under five percent, where it has remained. ${ }^{18}$ Lengthening the cost recovery period for non-residential property to 39 years in 1993 lowered its present value relative to that on residential.

\footnotetext{
16 Hendershott and Ling (1984) discuss optimal ex ante holdings periods for commercial real estate. Gau and Wang (1994) find an average holding period of eight years for commercial properties, while Fisher and Young (2000) find an average holding period of 11 years for institutional CRE investors. The Real Estate Research Corporation (RERC) surveys institutional real estate investors, appraisers, lenders, and managers throughout the U.S. on a quarterly basis about required rates of return, expected rental growth rates, going-in and going-out cap rates, and expected holding periods by major property type (see its quarterly Real Estate Report, www.rerc.com). From 20002015, the mean expected holding period for apartments and offices was 8.5 and 8.8 years, respectively.

17 Lower tax rates cut tax savings on yearly deductions and their present value by raising after-tax discount rate.

${ }^{18}$ Follain, Hendershott, and Ling (1987) interpret the lengthened tax depreciation schedules and increased capital gain tax rate introduced by TRA 1986 as a rational response to a decrease in the inflation rate.
} 
The present value of depreciation deductions increases with the assumed investment holding period because of the longer deferral of depreciation recapture income. For example, the mean value of taxdep increases from 5.3 percent with an assumed holding period of 10 years to 7.4 percent with a 14-year holding period and falls to 3.2 percent with a six-year holding period. However, since the Tax Reform Act of 1986 sharply reduced allowable depreciation deductions, taxdep is less sensitive to holding period assumptions.

The Lincoln Land Institute publishes a quarterly time series of the estimated land share for aggregate U.S. owner-occupied housing. ${ }^{19}$ This share averaged 33 percent in our sample and ranged from 25 to 46 percent. Similar data are not available for CRE properties. However, CRE competes with owner-occupied housing for land, thus movements in CRE land shares are likely correlated with movements in housing land shares. We also perform calculations in which the CRE land share varies in proportion to movements in the quarterly housing share reported by the Lincoln Land Institute. With this assumption our land share parameter value for CRE varies from 15.1 percent to 27.7 percent over the sample period. The effects of a time-varying CRE land share has an almost indiscernible effect on taxdep; the correlation of taxdep with time varying land shares to our base case taxdep is $0.9997 .^{20}$

\section{EFFECTIVE TAX RATES}

The present value of net depreciation benefits is a critical component of the federal taxation of real property. However, a more comprehensive measure of the impact of the federal income tax system on real estate investments is the effective tax rate (ETR), calculated as:

$$
E T R=\frac{I R R^{B T}-I R R^{A T}}{I R R^{B T}}
$$

\footnotetext{
19 See http://datatoolkits.lincolninst.edu/subcenters/land-values/.

${ }^{20}$ Details of calculating taxdep for varying land share and holding period assumptions are available upon request.
} 
where $I R R^{B T}$ and $I R R^{A T}$ are the before- and after-tax internal rates of return (IRR) on equity over an assumed investment holding period, respectively. Aside from depreciation benefits, ETR captures the taxation of expected rental income and nominal price appreciation at sale and the time-varying tax advantage of using debt to partially finance the acquisition.

The "typical project model" is often used to analyze income tax effects on user costs of capital and internal rates of return. ${ }^{21}$ This model begins with assumptions about the current and expected future levels of rents, operating expenses, and capital expenditures, expected vacancy and collections losses, the initial loan-to-value ratio, the mortgage interest rate, the expected selling price of the property at the end of an assumed holding period, allowable depreciation, the taxation of gains and losses on the sale of the property, and the marginal tax rates facing the marginal investor. The after-tax internal rate of return is the discount rate $(k)$ that equates the present value of the after-tax cash inflows and outflows over the $N$-year holding period with the acquisition price $\left(P_{o}\right)$. That is, equation (3) is solved for $k$.

$$
\begin{aligned}
P_{0}= & \sum_{t=1}^{N} \frac{\left(R_{t}-V C_{t}-O E_{t}\right)\left(1-\tau_{T B I}\right)}{(1+k)^{t}}-\sum_{t=1}^{N} \frac{C A P X_{t}}{(1+k)^{t}} \\
& +\sum_{t=1}^{N} \frac{\left(S L D E P_{t}+E X D E P_{t}\right) \tau_{T B I}}{(1+k)^{t}}-\frac{\left(\sum_{t=1}^{N} S L D E P \tau_{S L R}+\sum_{t=1}^{N} E X D E P \tau_{E X R}\right)}{(1+k)^{N}} \\
& +\frac{P_{N}}{(1+k)^{N}}-\frac{\left(P_{N}-\left(P_{O}+\sum_{t=1}^{N} C A P X_{t}\right)\right) \tau_{C G}}{(1+k)^{N}}+L_{0}-\frac{L_{N}}{(1+k)^{N}}-\sum_{t=1}^{N} \frac{P M T_{t}}{(1+k)^{t}}+\sum_{t=1}^{N} \frac{I N T_{t} \tau_{T B I}}{(1+k)^{t}} .
\end{aligned}
$$

The before-tax IRR is obtained as the $k$ when all tax rates are set equal to zero.

The first two summations track net operating income (NOI). $R_{t}, V C_{t}$, and $O E_{t}$ are, respectively, potential gross rental income, vacancy and collection losses, and deductible operating expenses. Annual rental income net of vacancies and operating expenses is taxed at

\footnotetext{
${ }^{21}$ For other applications of the typical project model to the taxation of CRE see, Brannon and Sunley (1976), Brueggeman, Fisher, and Stern (1981), Hendershott and Ling (1984) and Follain, Hendershott, and Ling (1987).
} 
the investor's marginal tax rate on trade or business property, $\tau_{T B I}$. CAPXt in the second summation denotes expected capital expenditures. Such cash expenditures are not deductible against ordinary income in the year incurred; rather, they are added to the property's tax basis and then depreciated. The third and fourth summations capture the net present value of depreciation deductions over a $N$-year holding period (summing to taxdep $P_{\mathrm{o}}$ ).

The market value of the property net of selling expenses is expected to rise to $P_{N}$ over the $N$-year holding period. $\left[P_{N}-\left(P_{O}+\sum_{t=1}^{N} C A P X_{t}\right)\right]$ represents the payment of capital gain taxes in year $N$ on the portion of the total gain from sale that exceeds the sum of the original acquisition cost plus subsequent capital expenditures. The present value of expected capital gain taxes in year $N$ is taxgain. On the sale of trade or business property held as a long-term investment (generally greater than 12 months), the owner is can treat the taxable gain or loss as a Section 1231 transaction (Manolakas and Anderson, 1990). Accordingly, a positive difference between the selling price in year $N$ net of selling expenses and the total amount invested in the property will be taxed at the investor's marginal capital gain tax rate, $\tau_{C G .}{ }^{22}$

The remaining four terms in equation (3) capture the net present value of debt financing, npvdebt. $L_{o}$ is the initial amount of the mortgage loan and $L_{N}$, the expected remaining mortgage balance at sale year $N$. The two sums are the present value of annual mortgage payments (including principal amortization) and the present value of annual tax savings from mortgage interest deductions, respectively. The sum of the four mortgage debt terms equals zero if the IRR (discount rate) equals the after-tax mortgage interest rate. If the IRR exceeds the after-tax mortgage interest rate, npvdebt will be positive. The impact of leverage on ETRs and cap rates is discussed in more detail below.

22 If a taxpayer has more than one Section 1231 transaction in a taxable year, the taxable gains and losses are netted. If those gains exceed losses, net gains are taxed as long-term capital gains. But, if taxable losses exceed the gains, the net loss is fully deductible against ordinary income (Manolakas and Anderson, 1990). 
We estimate the gross potential income in the first year of operation for our prototypical property using observed cap rates and assumptions regarding vacancies, expenses and $C A P X$. Because the cap rate equals the property's estimated net operating income (NOI) in the first year after acquisition $\left[R_{t}-\left(V C_{t}+O E_{t}, C A P X_{t}\right)\right]$ divided by the acquisition price, we multiply the cap rate by that price. We assume vacancy and collection losses are a constant five percent of gross rental income and operating expenses and capital expenditures consume 45 and five percent, respectively, of expected gross income each year. ${ }^{23}$ For comparing across property types, we assume owners pay all operating expenses in gross leases, implying an estimate of effective gross income. ${ }^{24}$ Quarterly data on cap rates, LTV ratios, mortgage rates, and loan maturities for offices and apartments are from the American Council of Life Insurers (ACLI) Commercial Mortgage Commitments - Historical Database. ${ }^{25}$

Life insurance companies generally provide long-term, fixed rate financing on newer high occupancy properties located in desirable markets. Their maximum loan-to-value-ratio, usually 65 percent, is below that of other investors. With less leverage and default risk, they generally offer lower interest rates. Because the type of property financed and the underwriting of those loans has been about flat over our sample period these data are well suited to tracking long-term trends in cap rates, CRE mortgage rates, and leverage ratios.

If a local CRE space market is in long-run equilibrium—demand for space equals supply (net of a normal vacancy rate), then real rents are not expected to change and nominal rents will grow at the rate of general inflation. We therefore assume nominal rents will grow at the expected (general) inflation rate over the 10-year expected holding period in a long-run

\footnotetext{
23 These assumptions are based on data from the National Council of Real Estate Investment Fiduciaries provided by Jeff Fisher. NCREIF is a not-for-profit institutional trade association that collects, processes, and disseminates information on the risk/return characteristics of CRE assets owned by institutional investors.

${ }^{24}$ For an acquisition price of $\$ 1,000,000$ and a cap rate of 5.7 percent, effective gross income on an investment is $\$ 114,000[(0.057 x \$ 1,000,000) /(1-0.45-0.05)]$. Potential gross income thus is $\$ 120,000[\$ 114,000 /(1-0.05)]$.

25 ACLI is a trade association with about 300 members in the U.S. and abroad. ACLI's Commercial Mortgage Commitments report on life insurers' mortgage lending tracks property type, contract rate, basis-point spread, debt coverage, LTV ratio and cap rate. The survey includes long-term (over one year) mortgage commitments on U.S. commercial properties. Loan data are aggregated and are released five to six weeks after a quarter's end.
} 
equilibrium. Our quarterly forecast of the annualized 10-year inflation rate is that used in the Federal Reserve Board's quarterly model of the U.S. economy. ${ }^{26}$

It is standard for CRE analysts to estimate the selling price in year $N$ by dividing the property's expected net operating income in year $N+1$ by an assumed going-out (terminal) cap rate. Because economic depreciation and functional obsolescence occur after a property is acquired, the terminal cap rate for stabilized properties is declining in the holding period. Based on RERC data, we assume the going-out cap rate increases, relative to the going-in cap rate, by seven basis points per year. ${ }^{27}$ Under a 10 -year holding period, this implies that the going out rate exceeds the initial cap rate in ACLI surveys by 70 basis points.

Figure 4 plots before- and after-tax real IRRs (nominal less expected inflation) and the average leverage ratio for offices. Both returns exhibit sharp negative trends over the sample, the pretax falling from 25 to six percent and the post-tax from 15 (20 in 1981) to four percent. Real IRRs for residential income property (not shown) display similar patterns. The strong correlation of the holding period rates of return with the leverage ratio is obvious.

Figure 5 plots effective tax rates for existing office and residential properties. Variations in tax law are the main cause of variation in effective tax rates. The sharp drop in the ETRs from 30 percent in 1980 to 5 percent in 1982 and the reversal to 20 percent in 1987 mirror the surge and fall in the present value of tax depreciation in Figure 3. The ETR did not rise to the pre1981 level after 1986 when the generous allowances were reversed owing to the sharp cut in the regular income tax rate; this rate was only 28 percent in 1988 versus 70 percent rate pre-1982. The rise in the rate from the early to middle 1990s reflects the increase in the regular income tax rate from 31 to almost 40 percent. The increase in the minimum cost recovery period for nonresidential real estate from 31.5 years to 39 years in the second quarter

\footnotetext{
26 The rate is a weighted average of one-year ahead forecasts of PCE inflation for each of the next ten years. The weights sum to one and decline geometrically at a rate based on the average duration of a ten-year bond. ${ }^{27}$ According to RERC's quarterly Real Estate Report, the mean going out cap rate assumed by investors on a stabilized office (apartment) property from 2000-2015 exceeded the mean going-in cap rate by 65 (62) basis points.
} 
of 1993, when that for residential was unchanged, opened up a three to five percentage point gap between their ETRs. The rise in ETRs in 2013 reflects higher tax rates on trade or business income, capital gain income, and depreciation recapture income.

Figure 6 shows the impact of taxes and the role of nontax factors by plotting the ETR for our prototypical office property from Figure 5 (the solid line) and a calculated ETR that holds nontax variables at their 1975Q1 values throughout (the holding economic-variablesconstant dashed line). Thus, this ETR series directly measures the impact of tax changes.

Differences in the two lines in Figure 6 reflect the extent to which nontax variables affected the ETR. The larger difference over 1988 to 1992 and the larger gap since owes to changes in the cap rate, the expected inflation rate (long run income growth rate), the commercial mortgage rate and leverage. Expected inflation and office market capitalization and mortgage rates are shown in Figure 7 (LTV is in Figure 4). During the key 1988-92 years, the cap rate increased approximately 100 basis points and expected income growth rate fell more than 150 basis points. As a result, a larger portion of the expected total return over the assumed 10-year holding period was in the form of higher taxed regular income and less in the form of lower taxed capital gain income. This shift drove up the ETR. Conversely, office cap rates fell 240 basis points from 2003Q1 to 2007Q4, pushing the ETR down.

The sharp widening of the gap between the ETR and the economic-variables-constant ETR in late 2008-2009 reflects the recent financial crisis, which pushed up mortgage rates and cap rates and lowered expected rates of inflation and rental growth. These changes combined to shift more of the holding period return to higher taxed regular income. This shift partially reversed after 2010 when cap rates fell and expected rent growth rose.

Our calculation of the ETR and taxdep are based on numerous assumptions. These include the use of leverage, the expected holding period of the investor, and other factors. The next four paragraphs discuss the sensitivity of the calculations to these assumptions. 
Unlike most acquisitions of bonds and stocks, the substantial use of debt financing by investors is pervasive in CRE markets. And, higher leverage increases taxdep relative to the amount of equity capital used to finance the purchase, thereby reducing ETRs. To illustrate the impact of leverage, the solid line in Figure 8 is the ETR for office properties assuming ACLI underwriting, while the dashed line is based on all equity financing. Unlevered ETRs always exceed levered ETRs, with the mean difference over our sample period being 8.1 percentage points. However, since 1987 the mean effect of leverage on ETRs is 4.0 percentage points, and the quarterly correlation of the levered and unlevered ETRs is 0.954.

As discussed above, the present value of depreciation deductions increases with the assumed investment holding period because of the longer deferral of depreciation recapture income. To quantify this, we recalculated our ETRs assuming holding periods of six years and 14 years, respectively. The going-out cap rate is assumed to increase by seven basis points per year. These alternative holding periods have little effect on ETRs. More specifically, the 27.2 percent average ETR assuming a six-year holding period is just 108 basis points greater than the 10-year mean, which is just 28 basis points higher than the 14-year mean. The correlation of the 10-year ETR with both the six- and 14-year ETR is $0.994 .^{28}$

To further investigate the sensitivity of ETRs to assumptions about the economic environment and the income producing ability of the prototypical property, we develop scenarios based on pessimistic (low IRR) and optimistic (high IRR) assumptions: vacancy and collection losses equal a constant 10 (zero) percent of gross rental income, operating expenses consume 50 (40) of gross income each year; capital expenditures consume eight (three) epercent, and the going-out cap rate increases relative to the initial cap rate by 10 (3) basis points per year. A 10-year holding period assumption is used in both alternative scenarios. To

\footnotetext{
${ }^{28}$ Section 1031 of the IRC permits taxpayers to defer recognizing some or all of the taxable gain on the disposition of business-use or investment assets by the use of a tax-deferred exchange. Thus, our estimated effective tax rate is an upward bound, especially in periods following rapid price appreciation when the tax motivation for using an exchange rather than a fully taxable sale is higher.
} 
the extent these alternative income productivity assumptions do not interact with taxation, their effects will zero out in the ETR calculations.

The solid line in Figure 9 reproduces our base-case ETRs for office properties. The dashed line that lies above this displays the ETRs for our pessimistic scenario. The diamondmarked line that lies below depicts the ETRs for our optimistic scenario. Over the sample period, the pessimistic scenario yields ETRs that average 546 basis points greater than the corresponding base-case ETRs. The mean ratio of the pessimistic to the base case is 1.27 . The optimistic scenario yields ETRs that average 335 basis points less than the corresponding basecase ETRs, with a mean ratio to the base case of 0.84 . The quarterly correlation of the optimistic and base ETRs is 0.983; that of the pessimistic and base ETRs is 0.993 . While the level differences of the ETRs are large, their quarterly correlations are high.

\section{ILLUSTRATING THE USEFULNESS OF OUR TAX DEPRECIATION VARIABLE}

Shifts in CRE taxation likely contributed to large swings in CRE prices and activity, which are difficult to explain without accurate gauges of taxation, such as ours. As an illustration, we show how our measure of the present value of tax depreciation allowances per dollar of investment helps explain movements in office and apartment cap rates.

Assume that in equilibrium a CRE version of the Gordon Growth model holds (see Duca and Ling, 2015). That is, net operating income $\left[R_{t}-\left(V C_{t}+O E_{t}, C A P X_{t}\right)\right]$ grows at an expected constant rate $g$, and going-out and going in cap rates are equal. Further assume that the marginal investor discounts expected $N O I$ s and the net capital gain, $P^{N}$-taxgain, at a constant rate $r$ and after-tax mortgage payments over the expected holding period at the after-tax mortgage rate. ${ }^{29}$ The equilibrium price, $P_{o}^{e}$, from equation (3) collapses to:

\footnotetext{
${ }^{29}$ Appropriately treating debt financing is critical. At the margin (or optimal LTV ratio), the after-tax cost of debt equals the cost of equity, with no advantage to debt. The average cost of debt is cheaper because debt is less risky. If the average cost of equity is used to discount mortgage payments over the expected holding period, npvdebt $>0$.
} 


$$
P_{o}^{e}=\frac{N O I_{1}}{r-g}+(\text { taxdep }) P_{o}^{e}-\text { taxgain } .
$$

Thus, competitively determined prices are equal to the value placed by the marginal investor on the unlevered cash flows (NOIs and $P^{M}$ ), plus the present value of the depreciation tax shield, minus the present value of capital gain taxes. From equation (4), it follows that:

$$
\frac{N O I}{P_{o}^{e}}=\text { CapRate }_{o}^{e}=(r-g)\left[(1-\text { taxdep })+\frac{\text { taxgain }}{P_{o}^{e}}\right] .
$$

Nominal asset prices and pretax required rates of return $(r)$ are determined in competitive markets and adjust to equate real, risk-adjusted, after-tax expected returns across assets. For example, pretax interest rates on 10-year Treasuries and the unlevered required real estate return $(r)$ rise when the tax rate on trade or business income or capital gains for the marginal investor rises, all else equal. Thus, changes in $r$ capture changes in the trade or business and capital gain tax rates applied to all financial assets, including the term taxgain/ $P_{o}^{e}$ in equation (5). However, the present value of tax depreciation affects the pricing of CRE but not of Treasuries. Thus the presence of $(\operatorname{taxdep}) P_{t}^{e}$ on the right side of equation (4) scales down the equilibrium cap rate in equation (5) by (1-taxdep), implying:

$$
\text { CapRate }_{o}^{e}=(r-g)(1-\text { taxdep })
$$

We proxy the expected long-run nominal growth in NOI with a measure of long-run inflation expectations. For the required rate of return, we use Duca and Ling's (2015) finding over 1996Q1-2015Q2, that the required unlevered before-tax return on office properties (Real Estate Research Corporation survey data) equals the 10-year Treasury yield plus a risk premium, estimated to equal the sum of a constant (1.92), a general risk premium (0.814 times the spread between Baa-rated corporate and 10-yr. Treasury yields), and the effective bank 
capital requirement on $\mathrm{CRE}$ (0.27 x effective capital requirement). We backcast this estimate to $1975 \mathrm{Q} 1$ to construct required return series for both offices and apartments.

However, there is good reason to believe that the riskiness of assets fell in the early 1980s. Inflation had been high and volatile in the late 1970s. When market interest rates rose above Regulation Q ("Reg Q") deposit rate ceilings, outflows of deposits occurred that induced banks to ration credit. The risk premium embedded in investors' required rates of return plausibly shifted down after the Volcker-led Fed gained credibility by lowering inflation and its associated risks, reflected in the ability of the term, $\left(r^{-} g\right)(1$-taxdep), to track cap rates after 1981 (Figure 10). Accordingly, a risk premium shift variable, InflatEra, equal to 1 before 1982Q1, and 0 since, is added to the above backed-casted estimate of the Duca-Ling risk variable. Although this shift variable ends one year before the Federal Reserve stopped targeting money in late 1982, late 1981 coincides with the large drop of inflation in 1981 when the equity premium fell notably according to Blanchard's estimates (1993, the chart on p. 102). The fall in inflation helped usher in the "Great Moderation"30 period, which, in turn, likely lowered CRE investment risk, consistent with evidence that the equity risk premium shifted down in the mid-1980s (Blanchard, 1993; Campbell and Vuolteenaho, 2004).

Taking the above considerations into account, we estimate two versions of the following error-correction model for both apartment and office cap rates:

$$
\begin{aligned}
& \text { CapRate } \left._{t}^{e}=\alpha_{0}+\alpha_{1}\left(r_{t}-g_{t}\right)\left(1-\text { taxdep }_{t}\right)\right]+\alpha_{2} \text { InflatEra }_{t}\left(1-\text { taxdep }_{t}\right)+v_{t} \text {, } \\
& \Delta \text { CapRate }_{t}=\beta_{0}+\beta_{1} E C_{t-1}+\sum \beta_{2 i} \Delta \text { CapRate }_{t-i}+\sum \beta_{3 i} \Delta\left[\left(r_{t}-g_{t}\right)\left(1-\text { taxdep }_{t-i}\right)\right] \\
& +\sum \beta_{4 i}\left[\Delta \text { InflatEra }_{t-i}\left(1-\operatorname{taxdep}_{t-i}\right)\right]+X_{t} .
\end{aligned}
$$

\footnotetext{
30 This era is generally seen as starting near the end of the Volcker disinflation of the early 1980 s through 2007.
} 
where CapRate* is the estimated equilibrium level from equation (7) and $E C_{t-1}=$ CapRate $_{t-1}-$ CapRate $_{t-1}^{*}$.

According to equation (7), equilibrium cap rate levels are driven primary by the three long-run factors embedded in the product $(r-g)(1-\operatorname{tax} d e p)$-discount rates that reflect both the risk-free opportunity cost of equity capital and the unlevered equity risk premium, the expected growth rate of NOI, and changes in the net present value of tax depreciation. Changes in short-run cap rates [equation (8)], in turn, are a function of the extent to which cap rates differ from their equilibrium level in the previous quarter, lagged changes in the cap rate, lagged changes in its long-run determinants, and four short run controls included in the vector $X$. A negative coefficient on the EC term would imply that any excess of the actual over the equilibrium cap rate would tend to be followed by a reversion toward equilibrium.

The short-run controls track unusual events that notably and temporarily affect cap rates, and are plausibly exogenous to the long-run variables. These include the bindingness of ceilings on deposit interest rates, which induced credit rationing that lowered property demand and pushed up cap rates, as well as dummies for the Carter Administration's credit controls and the failures of Continental Illinois in 1984 and Lehman Brothers in $2008 .{ }^{31}$

We estimate four variants of equations (7) and (8) for office and multi-family cap rates over the full 1976Q3:2015Q4 (152 observations) and the more recent 1988.Q1-2015.Q4 periods (112 observations). Full period results are likely dominated by the 1981 and 1986 tax acts. Estimates for the more recent period are not and do not reflect including several dummy variables: InflaEra, the Carter credit controls and the failure of Continental Illinois. The first

31 The first $(\operatorname{Reg} Q)$ is Duca and Wu's (2009) measure of how much Regulation Q was binding in quarter $\mathrm{t}-1$ (this tracks the difference between the market interest rate and the deposit rate ceiling) to reflect how funding shortfalls induced credit rationing. The second (CreditControl) is a dummy equal to 1 in 1980Q1 and 1980Q2 (0 otherwise) to control for credit rationing induced by federal government controls on loan growth that induced tighter credit standards, thereby depressing asset prices and raising cap rates. The third control differs in the two equations. In the office equation it reflects event risk from the failure of Lehman (Lehman = 1 in 2009Q1); in the apartment equation it also reflects event risk from the failure of Continental Illinois ( ContIllFail= 1 in 1984Q3). 
variant uses ( $r-g)$ as a regressor, while the second through fourth multiplies ( $r-g)$ by (1-taxdep), where taxdep is based on expected holding periods of 6, 10 and 14 years, respectively. If the marginal CRE investor were a nontaxed institution, the first variant would outperform the others. The issue is whether depreciation tax savings lower cap rates beyond the positive effect of taxation incorporated in before-tax interest rates generally.

The estimation of long-run and short-run relationships is joint following Johansen (1995), and the vector error-correction framework allows for the endogeneity of the long-run variables but also to test which variables Granger-cause the others in the long-run. The number of lags was selected based on minimizing the Akaike Information Criterion. Allowing for some slight differences in lag lengths, the longest common sample period for the apartment cap rates is 1976Q3-2015Q4 and that for office cap rates is 1976Q3-2015Q4. The estimation assumptions allow for a linear trend in the data, as well as an intercept-but not a trend-in the cointegrating vector. These assumptions allow for possible time trends in long-run variables but not an independent time effect in the vector that would pick up, in an ad hoc way, influences outside of those tracked by the long-run factors in each model.

The upper-panel of Table 2 reports the results for the long run equilibrium office cap rate for both samples. The regressors are a constant and the $(r-g)$ and InflatEra variables, first alone and then interacted with (1-taxdep). A unique and statistically significant long-run (cointegrating) relationship is identified in each model, implying that there is one significant long-run relationship among the long-run variables that yields stationary residuals. In these cases, the hypothesis of no cointegrating vector or of two or more cointegrating vectors is rejected based on trace and maximum eigenvalue test statistics.

Consider the full period results. Consistent with theory, the office cap model using (1taxdep) has a long-run coefficient on $(\mathrm{r}-\mathrm{g})$ that is less than one standard deviation from the expected unity value for all expected holding periods and nearly equals unity for the 10 year 
period. Also, cap rates were significantly higher (about two percentage points) before the great moderation (as were stock earnings-to-price ratios, Blanchard, 1993), as implied by the significant coefficient on InflatEra*(1-taxdep).

Results from modeling the changes in office cap rates are reported in the lower panel of Table 2. The estimated quarterly speed of adjustment is effectively zero when $(r-g)$ is not interacted with the tax depreciation variable, but is a fifth and is highly significant with the expected sign in the tax-depreciation models. Moreover the adjusted $\mathrm{R}^{2}$ increases by a fifth (from 0.35 to 0.42 ). Accounting for changes in the present value of tax depreciation allowances notably improves our ability to explain changes in office cap rates.

Coefficients on the added short-run variables are significant and positive, indicating that cap rates are elevated by government regulations that restrict the supply of credit (the 1980 credit controls and Regulation Q) and by the failures of major financial institutions. These findings are plausible as both types of effects lower the effective demand for property, thereby raising cap rates. Furthermore, these effects are economically substantial; fits are 0.1 to 0.2 higher than those of corresponding models (not shown) that omit them. ${ }^{32}$ Finally, the results are not sensitive to the expected holding period upon which the tax depreciation variable is based. This is not surprising given the strong correlation of these series. ${ }^{33}$ The effects of a time-varying CRE land share has an almost indiscernible effect on taxdep; the correlation of taxdep with time varying land shares to our base case taxdep is 0.9997 .

Results for the 1988Q1-2015Q4 period are on the right side of Table 2. To save space, the better-fitting models using 10 and 14 year holding periods for tax depreciation are shown, along with the model omitting taxes. Results are very similar to those of the full period,

\footnotetext{
${ }^{32}$ It is reassuring that omitting the short-run variables does not (1) appreciably alter the estimated coefficient on the required rate of return minus expected rent growth or (2) weaken the cointegration results for the tax depreciation or no tax models.

33 The correlation of taxdep assuming a 6-year holding period and taxdep assuming a 10-year holding period is 0.9997. The 10-year and 14-year correlation is 0.9995 .
} 
implying the model holds for the large tax changes before 1988 and for the minor changes since then.

The multi-family cap rate model estimates, shown in Table 3, are quite similar to those for offices with a few differences. For the full period, the inflation era risk premium is greater (3.2 percentage points versus 2.0), and the explanatory power is a higher 0.54 versus 0.42 . More important, in model 1 , which omits tax depreciation, the coefficient on $\left(r^{-} g\right)$ is significantly less than unity in contrast to the coefficient on $(r-g)$ interacted with (1-taxdep). The explanatory power is 27 percent greater than offices for the full estimation period, but is 10 percent less for the shorter more recent period.

The actual cap rate and the equilibrium rates predicted by models 1 (no taxdep interaction) and 2 (with the interaction) are plotted in Figure 11. The estimated equilibrium cap rates track broad movements in the actual. These include the fall in the late 1970s, the jump in early 1980, the decline through most of the rest of the 1980s and the downward trend from 1993 to 2015, including the temporary bounce in 2009. The broad movements of the cap rate are caused by movements in $r^{-} g$.

But serious problems are evident when shifts in taxdep are not accounted for (Model 1). Most obvious is the large overestimate of the cap rate before 1982, which is offset by the underestimate since 1992, especially since 2002. A measure of the improvement due to accounting for taxdep is reflected in the mean squared differences between the actual and estimated equilibrium levels, which for model 1 (1.666) is more than twice as much as in model 2 (0.725). In terms of helping minimize squared errors in estimating cap rate changes, this difference is consistent with the EC term—which reflects information from estimated long-run relationships_-being insignificant for explaining cap rate changes in model 1 versus being statistically significant in model 2 . 
Results also imply that required returns and tax depreciation Granger cause office cap rates in the long-run, but not vice versa (see Granger and Lin, 1995). The significant EC term implies that the cap rate is not weakly exogenous to the tax depreciation-adjusted spread between the required rate of return and rent growth. The insignificant error-correction terms (not shown) in the short-run VECM models for this required rate of return spread imply that this fundamental is weakly exogenous to the cap rate, but the cap rate is not weakly exogenous to the driver. Details are available upon request. These results accord with two fundamental assumptions in deriving the cap rate equations; the main component of real required returns is determined in capital markets and the present value of tax depreciation affects prices. However, we find bi-directional, long-run causality between multi-family cap rates and ( $r-g)\left(1^{-}\right.$ taxdep). One plausible reason for the difference is that multi-family cap rates also reflect conditions in housing markets, ${ }^{34}$ which, in turn, has larger feedbacks on the macro-economy and investor returns than is the case for office cap rates.

\section{CONCLUSION}

Our study begins by documenting the evolution of U.S. tax law regarding CRE since 1975, noting changes in income and capital gains tax rates and tax depreciation methods. The most prominent changes were the 1981 and 1986 tax acts, but numerous significant changes have occurred in the last dozen years.

We compute the present value of tax depreciation per dollar of acquisition price, an important driver of CRE cycles. This percentage of value leaped from about 10 percent in the second half of the 1970s to over 20 percent in 1981 and remained above 12 percent through 1986. It then plunged to two percent in 1988 and has stayed below five percent since.

We also compute an effective tax rate for CRE, defined as the difference between the before and after tax expected internal rates of return, divided by the before-tax return. This

\footnotetext{
34 Aron, et al. (2012) and Duca and Muellbauer (2014) stress how house prices have large effects on U.S. consumption, the largest component of GDP, a feedback channel not involving office property.
} 
series mirrors our tax depreciation series from 1975 to 1987, falling from 35 to five percent before rebounding to 18 percent. It has since risen to 35 percent, reflecting higher tax rates.

The major difference between $\mathrm{CRE}$ and financial assets is the tax depreciation deduction allowed the former. Theory implies that it is a significant determinant of CRE pricing relative to that of financial assets, and we find that it is. We explain the capitalization rate of $\mathrm{CRE}$, the inverse of the income multiplier (the income-to-price ratio) using an error correction framework. We find that the long run estimates are statistically significant in the way theory suggests. Moreover, required financial asset returns and the tax depreciation variable temporally predate ("cause") office capitalization rates in the long run, but not vice versa. These findings_-namely that required rates of return are primarily determined in capital markets and that tax changes can matter a great deal-are consistent with the underlying assumptions we use to motivate what drives long-run CRE valuations. Our study's main contribution is to provide time series evidence by empirically modeling tax variables and office and apartment capitalization rates over the past four decades.

\section{References}

Antoniades, Adonis, "Commercial Bank Failures during the Great Recession: The Real (Estate) Story,” SSRN Electronic Journal 09/2013; DOI: 10.2139/ssrn.

Aron, Janine, John V. Duca, John Muellbauer, Keiko Murata, and Anthony Murphy, 2012. "Credit, Housing Collateral and Consumption in the UK, U.S., and Japan." Review of Income and Wealth 58, 397-423.

Autin, Gerald and Joseph Cordes, 1991. "Cutting Capital Gains Taxes.” Journal of Economic Perspectives 5, 181-192.

Autin, Gerald and Charles Clotfelter, 1982. "Permanent vs. Transitory Effects and the Realization of Capital Gains.” Quarterly Journal of Economics 97, 613-632.

Bailey, Martin J., 1974. "Progressivity and Investment Yields un U.S. Income Taxation." Journal of Political Economy 82 (6), 1157-1175.

Bernanke, Ben S., and Cara S. Lown, 1991. "The Credit Crunch," Brookings Papers on Economic Activity, no. 2, 205-47. 
Blanchard, Olivier J., 1993. "Movements in the Equity Premium," Brookings Papers on Economic Activity 2, 75-118.

Bokhari, Sheharyar and David Geltner, 2016. "Commercial Buildings, Capital Consumption and the United States National Accounts, MIT Center for Real Estate Working Paper.

Brannon, Gerard .M. and Emil M. Sunley, Jr., 1976. "The Recapture of Excess Depreciation on the Sale of Real Estate.” National Tax Journal 29 (4), 413-423.

Browne, Lynn E., and Karl E. Case. 1992. "How the Commercial Real Estate Boom Undid the Banks," in Lynn E. Browne and Eric S. Rosengren,eds., Real Estate and the Credit Cr unch, Federal Reserve Bank of Boston Conference Series no. 36.

Brueggeman, William B., Jeffrey D. Fisher, and Jerrold J. Stern, 1981. "Federal Income Taxes, Inflation and Holding Periods for Income-Producing Property." Journal of the American Real Estate and Urban Economics Association 9, 148-164.

Burman, Leonard and William Randolph, 1994. "Measuring Permanent Responses to Capital-Gains Tax Changes in Panel Data." American Economic Review 84(4), 794-809.

Campbell, John Y., and Tuomo Vuolteenaho, 2004. "Inflation Illusion and Stock Prices." American Economic Review, 94 (2), 19-23.

Duca, John V. and David C. Ling, 2015. "The Other (Commercial) Real Estate Boom and Bust: The Effects of Risk Premia and Regulatory Capital Arbitrage." Federal Reserve Bank of Dallas Working Paper No. 1504.

Duca, John V. and John Muellbauer, 2014. "Tobin LIVES: Integrating Evolving Credit Market Architecture into Flow of Funds Based Macro-Models." In A Flow-of-Funds Perspective on the Financial Crisis Volume II, Palgrave-Macmillan, B. Winkler, A Van Riet, and P. Bull (eds.), 11-39.

Duca, John V. and Tao Wu, 2009. "Regulation and the Neo-Wicksellian Approach to Monetary Policy.” Journal of Money, Credit, and Banking 41 (3), 799-807.

Feldstein, Martin and Joel Slemrod, 1979. "Inflation and the Excess Taxation of Capital Gains on Corporate Stock." National Tax Journal 31, 107-188.

Fisher, Jeffrey D. and Michael S. Young, 2000. "Holding Periods for Institutional Real Estate in the NCREIF Database." Real Estate Finance 17 (3), 27-34.

Follain, James R., Patric Hendershott, and David C. Ling, 1987. "Understanding the Real Estate Provisions of Tax Reform: Motivation and Impact." National Tax Journal, 363-372.

Follain, James R., Patric Hendershott, and David C. Ling, 1987. "Effects on Real Estate," in Evaluating Tax Reform, J. Pechman (ed.), Brookings Institution, 71-94.

Gau, George W., and Ko Wang, 1994. "The Tax-Induced Holding Periods of Real Estate Investors: Theory and Empirical Evidence.” Journal of Real Estate Finance and Economics 8, 71-85. 
Granger, C. W. J. and J.L. Lin, 1996. “Causality in the Long Run.” Econometric Theory 11 (3), 530-536.

Gravelle, Jane G., 1994. The Economic Effects of Taxing Capital Income. Ch. 6, Cambridge Mass. And London: MIT Press.

Hendershott, Patric H. and Edward J. Kane, 1992. "The Causes and Consequences of the 1980s Commercial Real Estate Boom." Journal of Applied Corporate Finance, 61-70.

Hendershott, Patric H. and David C. Ling, 1984. "Trading and the Tax Shelter Value of Depreciable Real Estate." National Tax Journal, 213-223.

Hulten, Charles R. and Frank C. Wykoff, 1981. "The Measurement of Economic Depreciation," in Depreciation, Inflation, and the Taxation of Income from Capital, ed. Charles R. Hulten, Urban Institute Press, Washington, D.C., 81-129.

Hulten, Charles R. and Frank C. Wykoff, 1996, "Issues in the Measurement of Economic Depreciation: Introductory Remarks.” Economic Inquiry 34 (1), 1023.

Ihlanfeldt, Keith R., 2011. "Do Caps on Increases in Assessed Values Create a Lock-in Effect? Evidence from Florida's Amendment One." National Tax Journal 64, 7-26.

Manolaksa, Thomas G. and Paul E. Anderson, 1990. Tax Factors in Real Estate Operations $7^{\text {th }}$ ed., Prentice Hall.

Penick, William P., 1983. "Evolution of the Federal Tax System: 1954-1983," Federal Tax Policy Memo 7(2), Tax Foundation, Incorporated.

Robinson, Gerald J., 1984. Federal Income Taxation of Real Estate, Warren, Gorham, and Lamont.

Sinai, Todd, and Joseph Gyourko, 2004. "The Asset Price Incidence of Capital Gains Taxes: Evidence from the Taxpayer Relief Act of 1997 and Publicly-traded Real Estate Firms." Journal of Public Economics 88, 1543-1565. 


\section{Figure 1: Commercial real estate income reported by adjusted gross income}

Data obtained from the 2014 IRS Statistics of Income (SOI). The tax consequences of CRE ownership in non-exchanged-traded securities are reported on Schedule E (row 3) of Form 1040 under rents received from direct investments in individual properties (solid bars) or income or loss from partnerships (row 32), including limited liability companies, and $\mathbf{S}$ corporations (cross-hatched bars). The vertical axis displays the percent of taxpayers reporting each type of income.

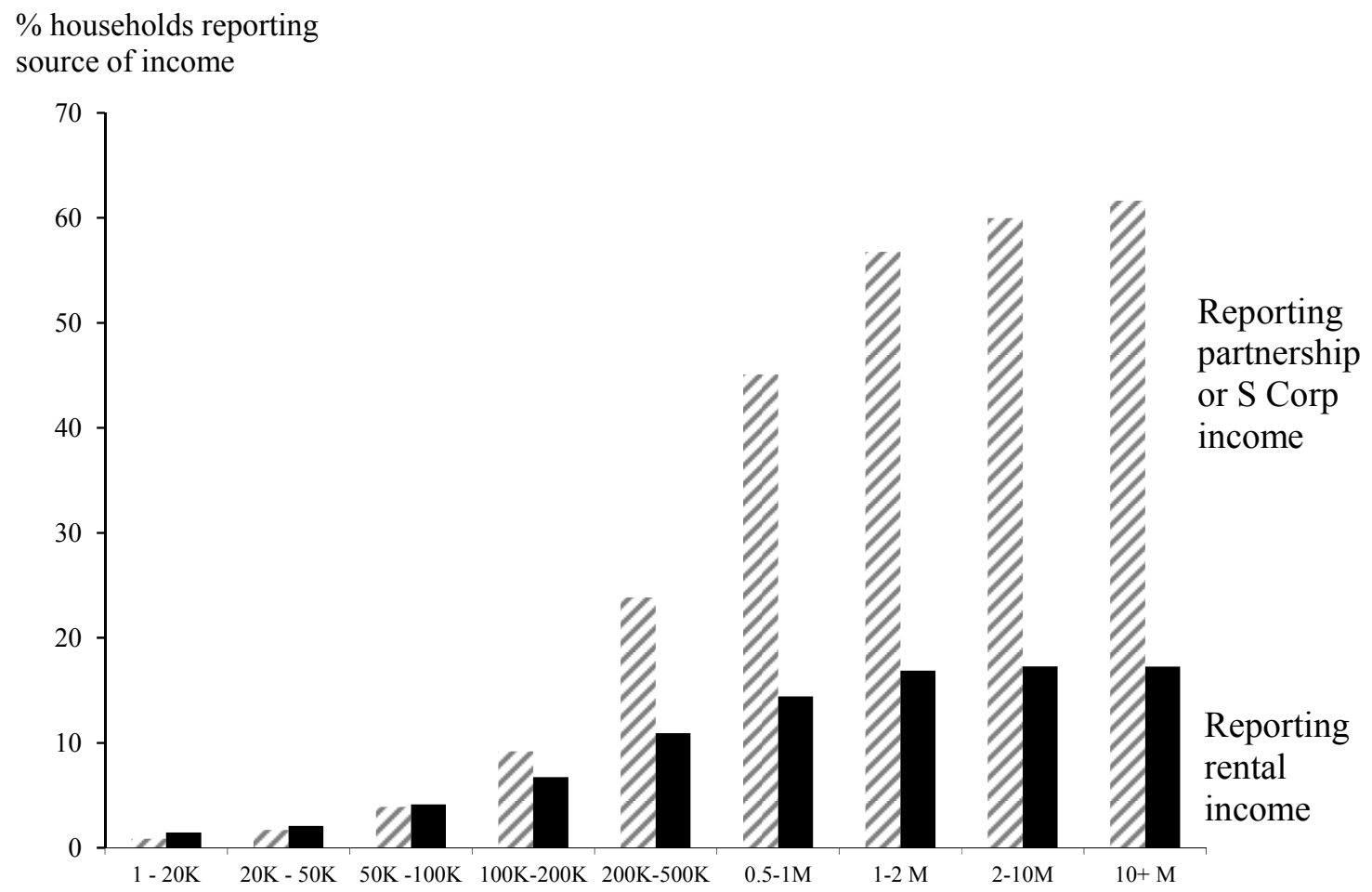


Figure 2: Maximum tax rates on Section 1231 trade or business income \& capital gain income

This figure plots maximum statutory tax rates on trade or business income and capital gain income. These rates do not include state income taxes or the effects of phasing out, since 1986, the itemized deductions and personal exemptions for higher income households. The rates do include the effects of the Net Investment Income Tax surcharge that has applied to higher income households since the passage of the American Taxpayer Relief Act of 2012.

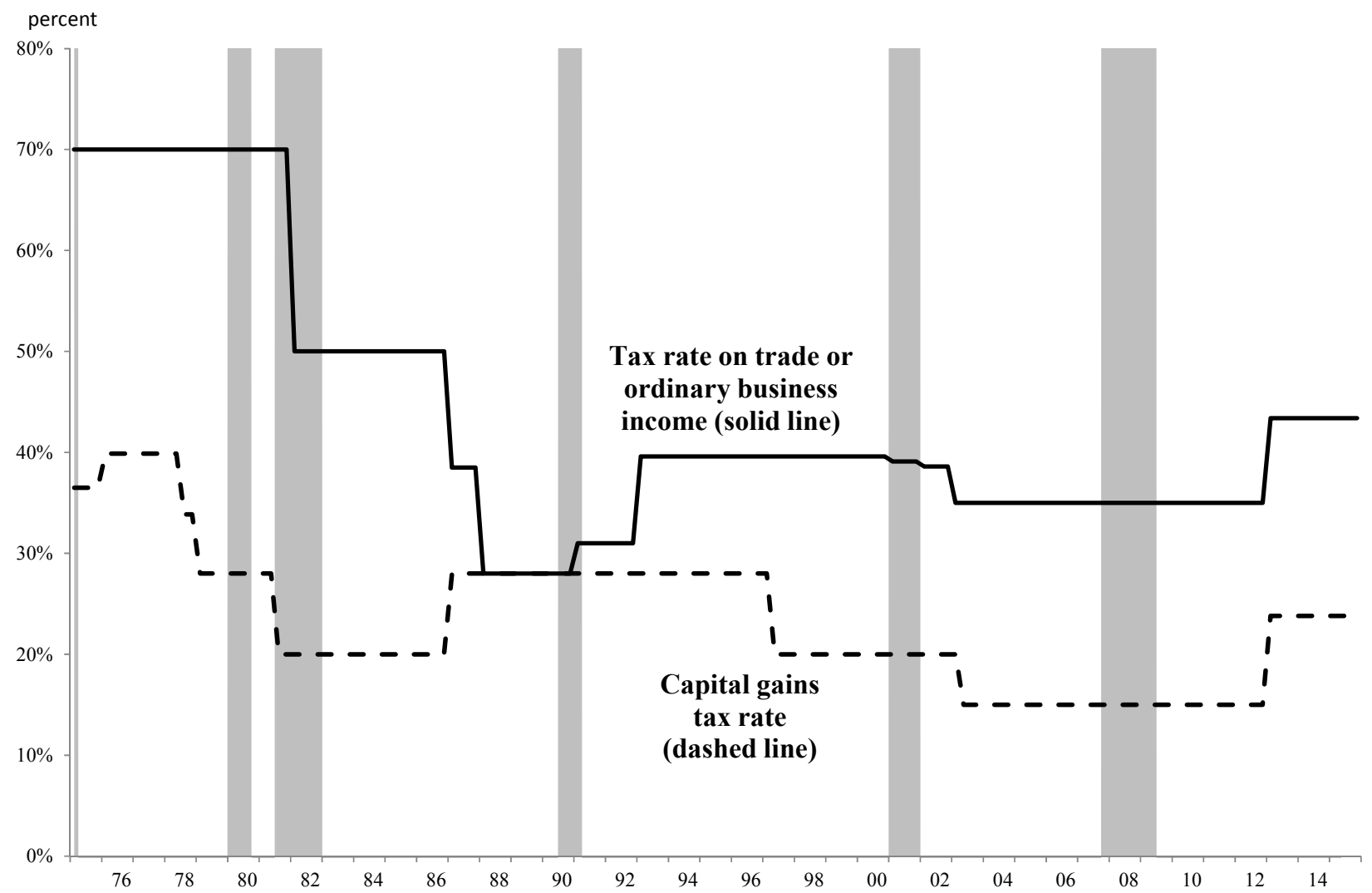

Shaded areas denote recessions. 
Figure 3: Present value of net depreciation deductions as a percentage of acquisition price

This figure plots the present value of net depreciation deductions as a percentage of the acquisition price for both used commercial and residential property. Land accounts for 20 percent of the acquisition price, there is no personal property, and the property is expected to be held for 10 years before being disposed of in a fully taxable sale. The discount rate used each quarter is the after-tax yield (IRR) on 10-year Baa-rated corporate bonds. The tax rate on trade or business income is used to calculate the after-tax discount rate for net depreciation deductions.

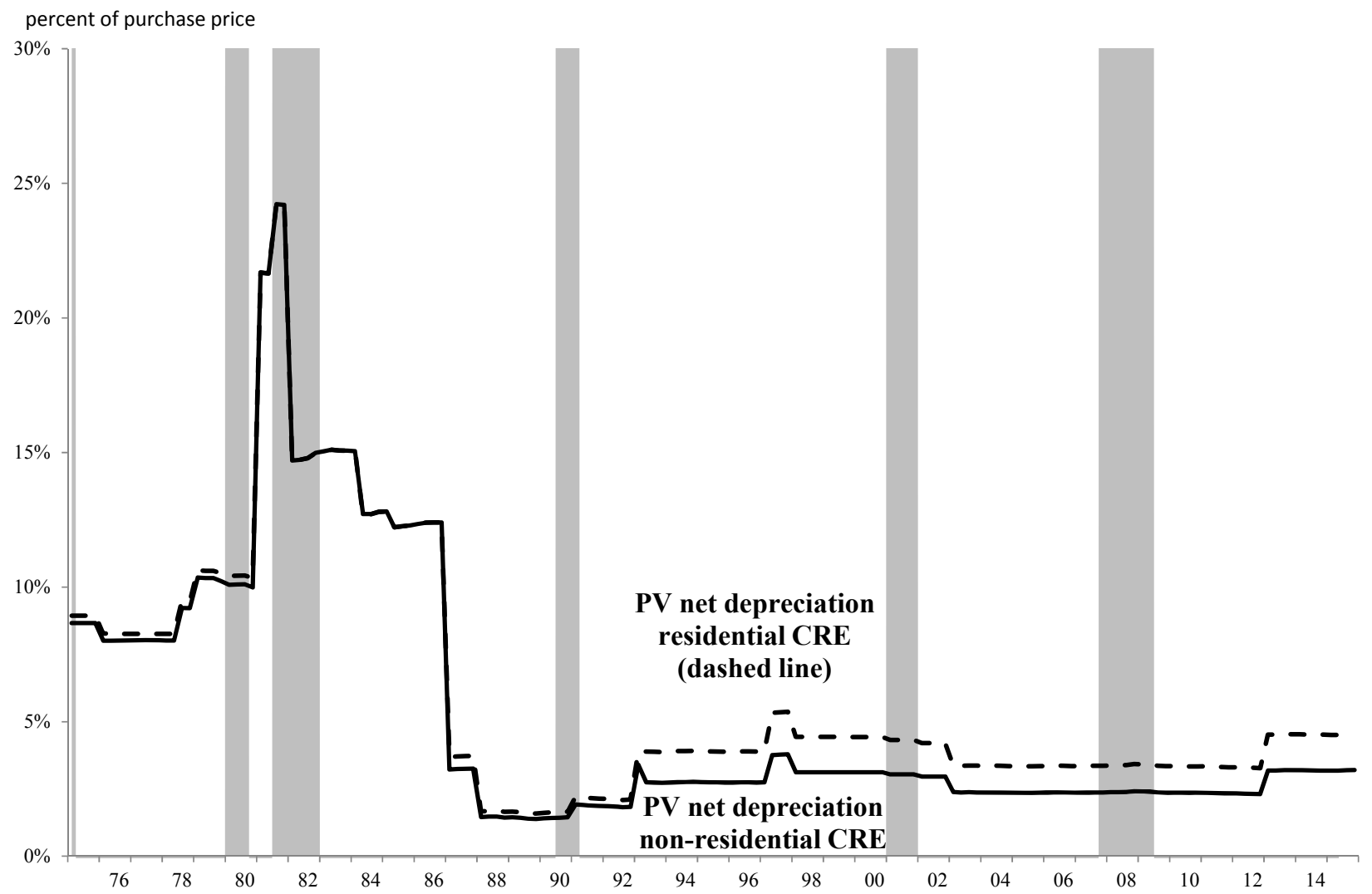

Shaded areas denote recessions. Sources: authors' calculations. 
Figure 4: Real before and after-tax internal rates of return and leverage

Vacancy and collection losses equal a constant five percent of gross rental income and operating expenses and capital expenditures consume 45 and five percent, respectively, of expected gross income each year. An estimate of the gross potential income in the first year of rental operations is obtained using observed cap rate data. Data on quarterly cap rates are from the American Council of Life Insurers (ACLI) Commercial Mortgage Commitments - Historical Database, as are loan-to-value ratios, contract interest rates, and loan maturities. Nominal rents grow at the expected (general) inflation rate over the 10-year expected holding period (that used in the Federal Reserve Board's quarterly model of the U.S. economy. The selling price in year $N$ is obtained by dividing the property's expected net operating income in year $N+1$ by an assumed going-out (terminal) cap rate. The going-out cap rate in each quarter is 60 basis points greater than the going-in cap rate reported by the ACLI.

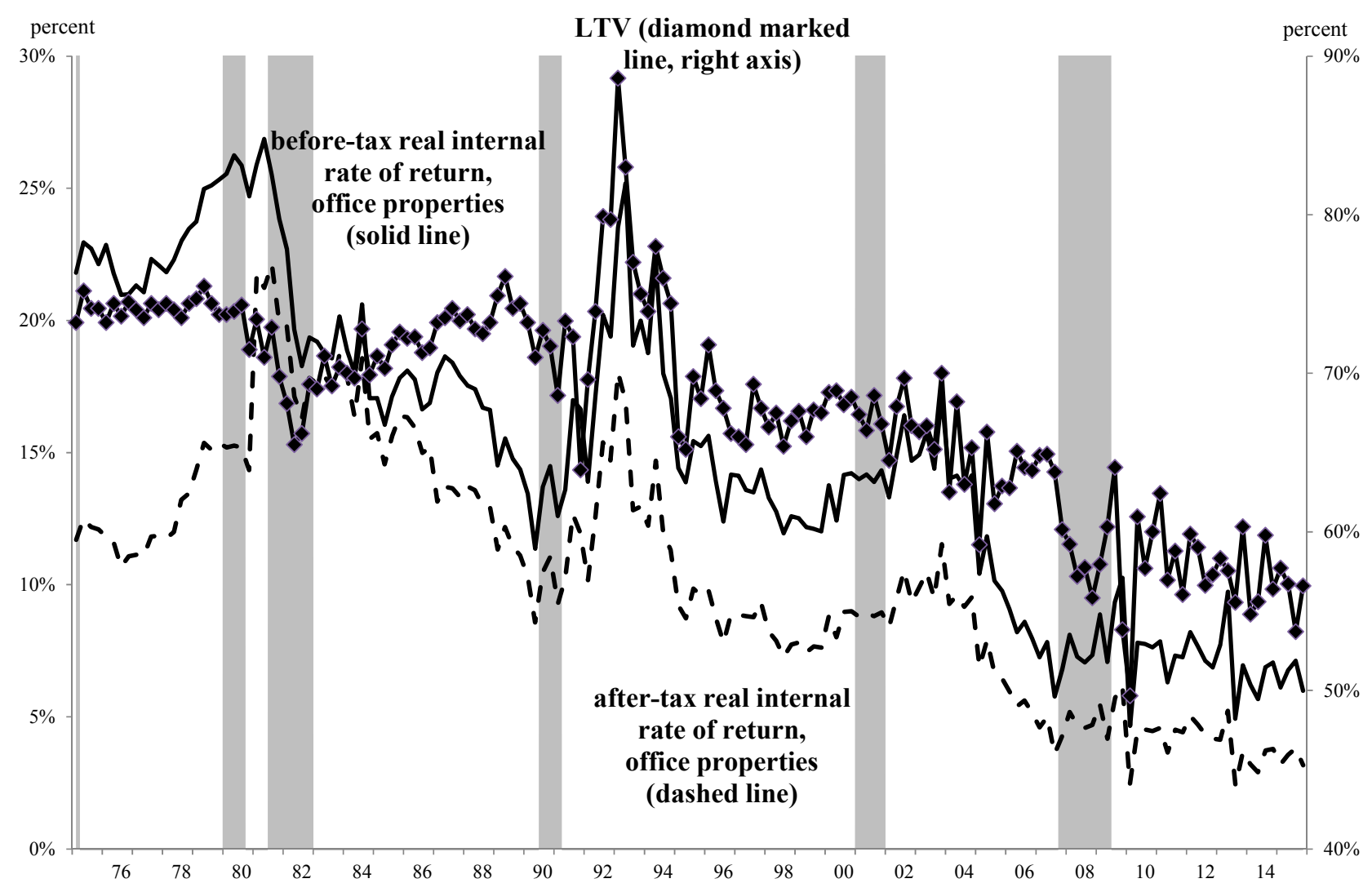

Shaded areas denote recessions. Sources: authors' calculations. 


\section{Figure 5: Effective tax rates for used office and residential properties}

The effective tax rate on is the difference between the before and after-tax expected internal rates of return (IRRs) divided by the before-tax IRR. Vacancy and collection losses equal a constant five percent of gross rental income and operating expenses and capital expenditures consume 45 and five percent, respectively, of expected gross income each year. An estimate of the gross potential income in the first year of rental operations is obtained using observed cap rate data. Data on quarterly cap rates are from the American Council of Life Insurers (ACLI) Commercial Mortgage Commitments - Historical Database, as are loan-to-value ratios, contract interest rates, and loan maturities for each of the major property types. Nominal rents grow at the expected (general) inflation rate over the 10-year expected holding period. Our quarterly forecast of the annualized 10-year inflation rate is that used in the Federal Reserve Board's quarterly model of the U.S. economy. The selling price in year $N$ is obtained by dividing the property's expected net operating income in year $N+1$ by an assumed going-out (terminal) cap rate. The going-out cap rate in each quarter is 60 basis points greater than the going-in cap rate reported by the ACLI for each property type.

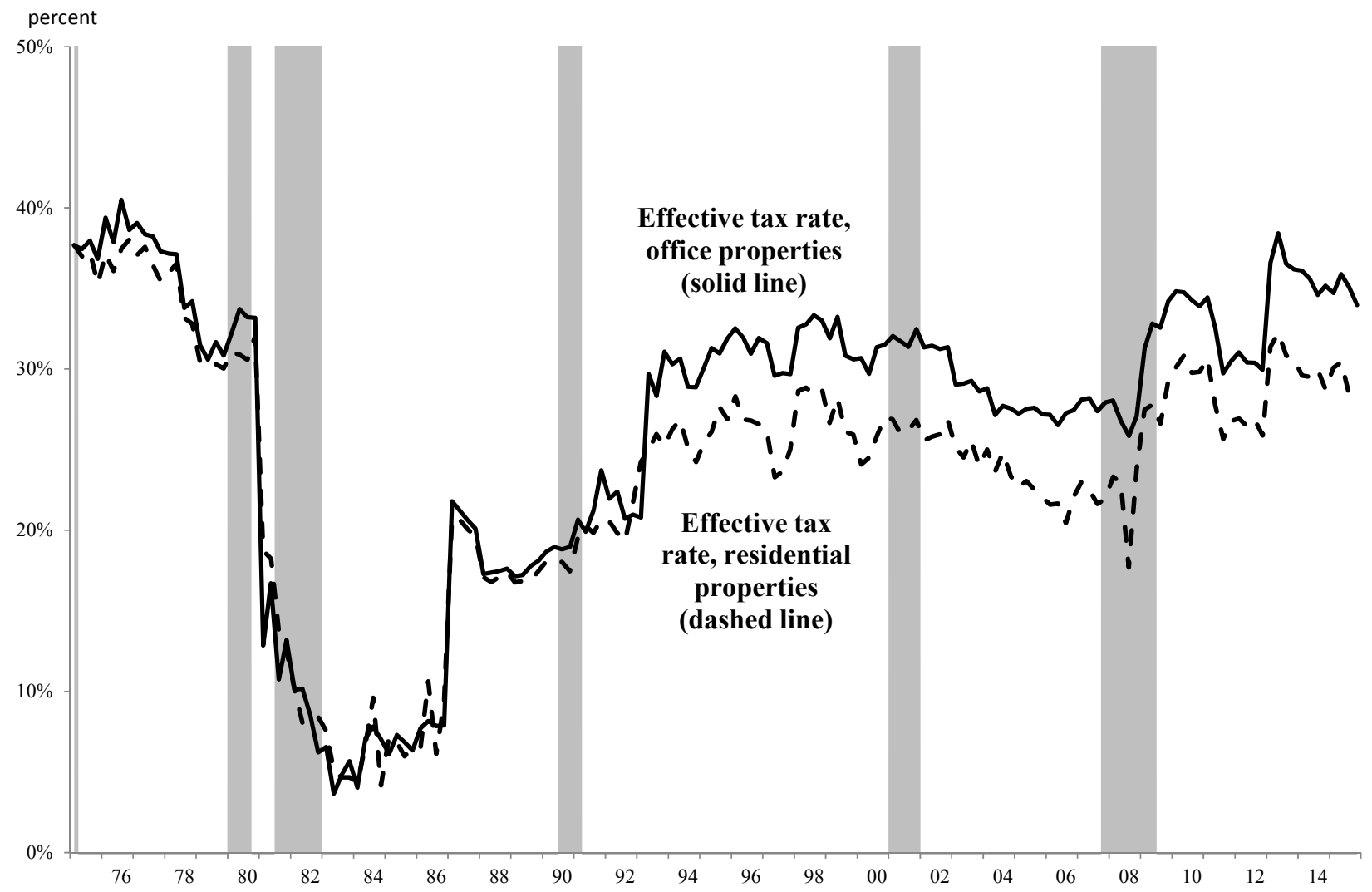

Shaded areas denote recessions. Sources: authors' calculations. 


\section{Figure 6: Isolating nontax changes in ETRs on office properties}

The solid line represents the effective tax rate for office properties (reproduced from Figure 5). The dashed line is the ETR for office properties assuming the nontax variables in place in 1975Q1 remained constant throughout the sample. Differences in the two lines capture the extent to which movements in nontax economic variables have affected the ETR. Other assumptions include: vacancy and collection losses equal a constant five percent of gross rental income; operating expenses and capital expenditures consume 45 and five percent, respectively, of expected gross income each year. Gross potential income in the first year of rental operations comes from cap rate data obtained from the American Council of Life Insurers (ACLI) Commercial Mortgage Commitments-Historical Database. Loan-to-value ratios, contract interest rates, and loan maturities are also from ACLI. Nominal rents grow at the expected (general) inflation rate over an assumed 10-year expected holding period. The quarterly forecast of the annualized 10-year inflation rate is from the Federal Reserve Board. The selling price in year $N$ is obtained by dividing the property's expected net operating income in year $N+1$ by an assumed going-out cap rate, which is assumed to be 60 basis points greater than the going-in ACLI cap rate.

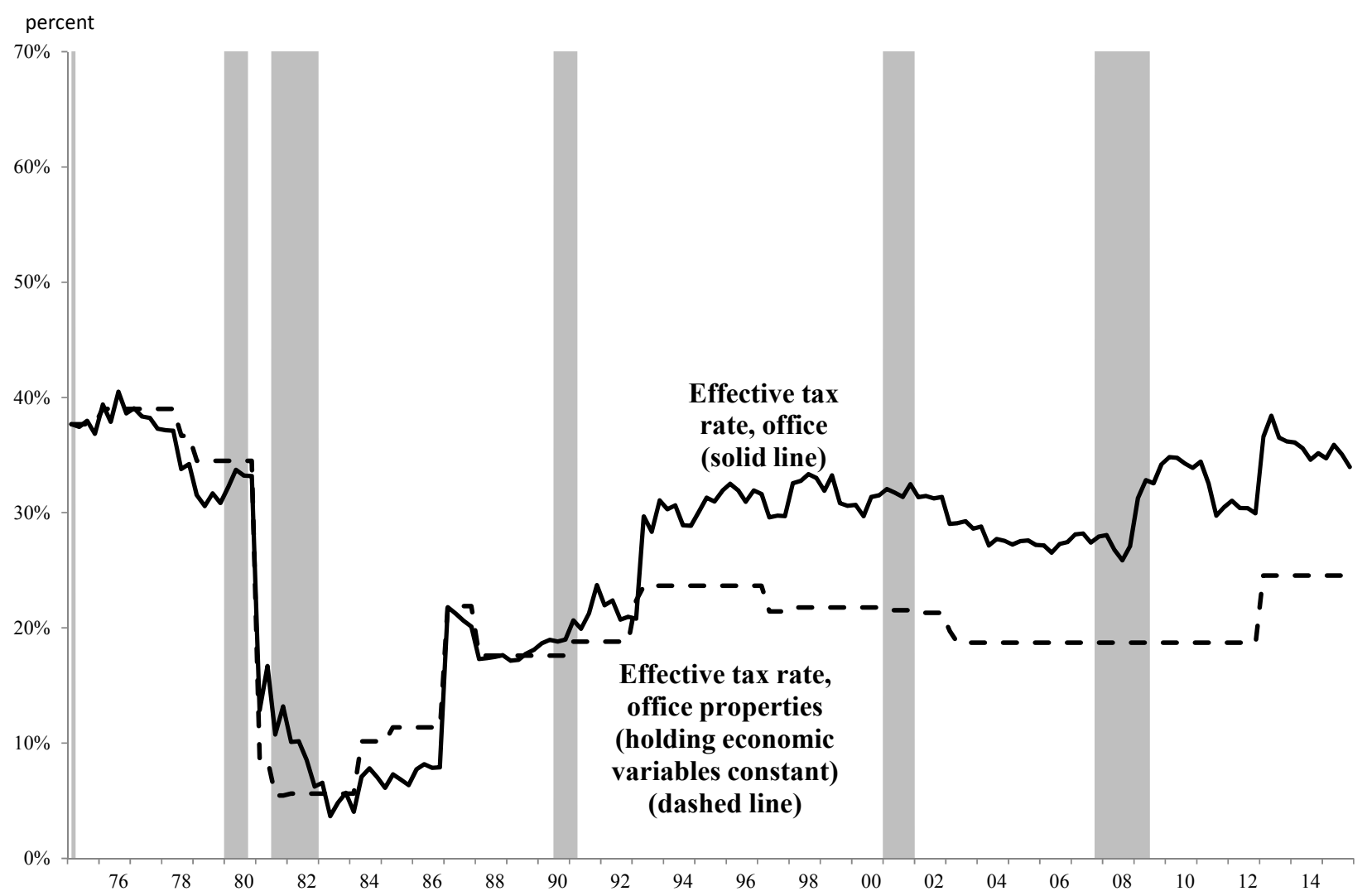

Shaded areas denote recessions. Sources: authors' calculations. 
Figure 7: Nontax determinants of IRR and ETR of office properties

Capitalization rates and office mortgage rates are from the American Council of Life Insurers (ACLI) Commercial Mortgage Commitments-Historical Database. The growth rate in potential gross income is the forecast of the 10-year inflation rate used in the Federal Reserve Board's quarterly model of the U.S. economy. The discount rate used to determine the present value of net depreciation deductions is the after-tax yield in 10-year Baa rated corporate bonds.

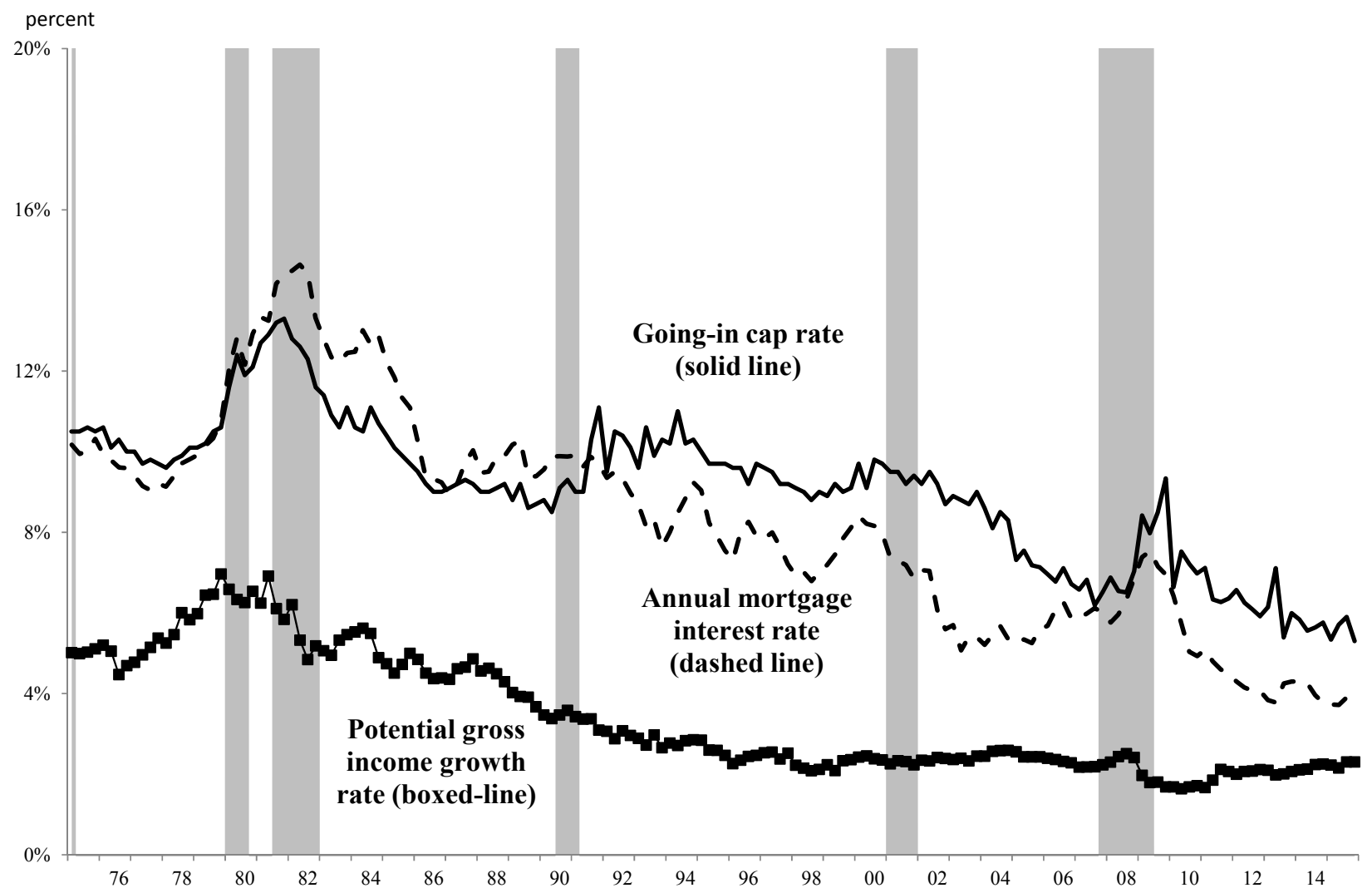

Shaded areas denote recessions. Sources: ACLI, Moodys, and authors' calculations. 


\section{Figure 8: Leverage and Effective Tax Rates}

The solid line reproduces the ETR for office properties assuming ACLI underwriting (loan of 65 percent of property); the dashed line is based on all equity financing.

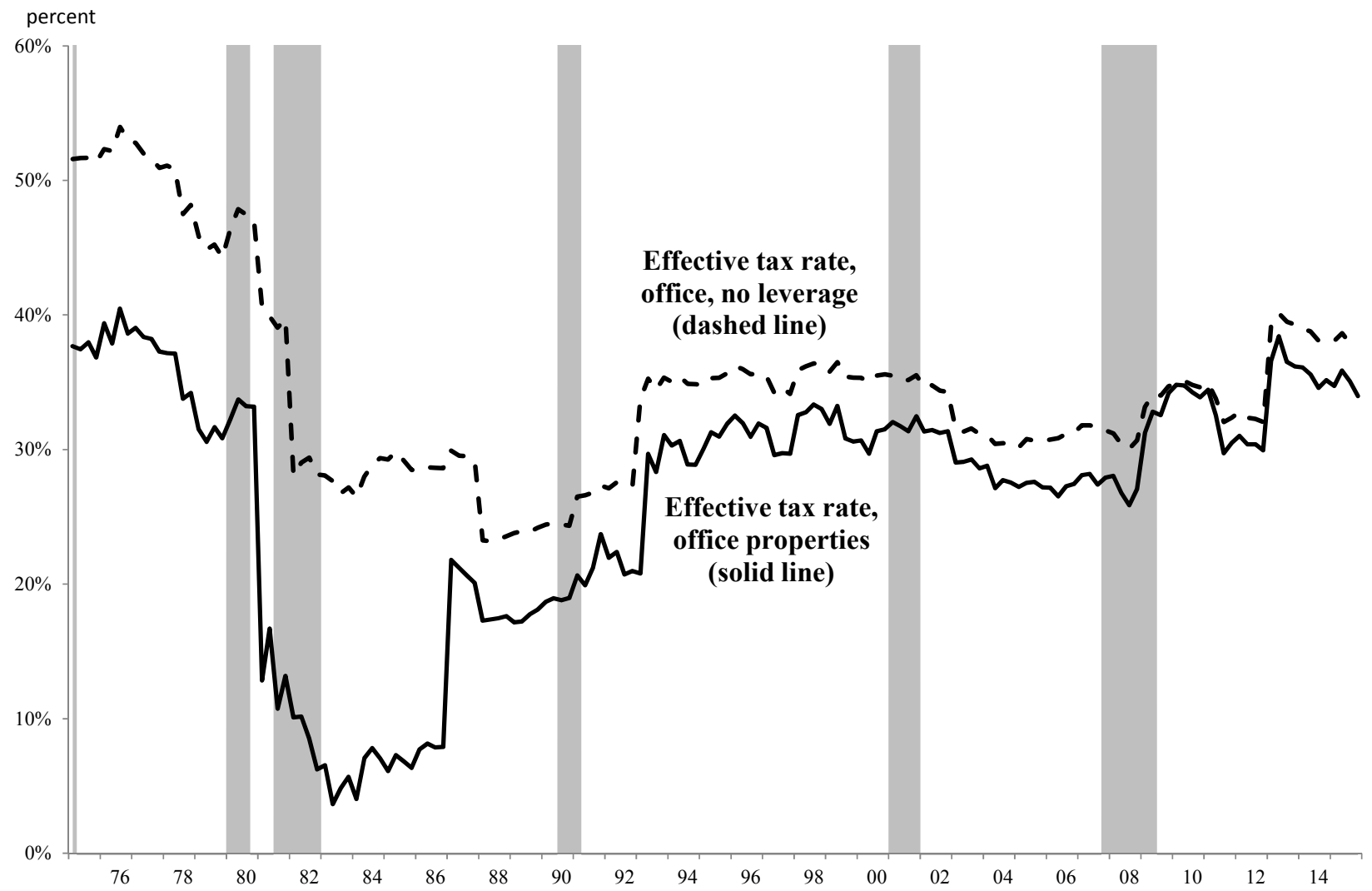

Shaded areas denote recessions. Sources: authors' calculations. 
Figure 9: ETRs with varying assumptions about the income producing ability of the property

In the pessimistic scenario, vacancy and collection losses equal a constant 10 percent of gross rental income and operating expenses and capital expenditures consume 50 percent and eight, respectively, of expected gross income each year. The going-out cap rate is assumed to increase 10 basis points per year. In the optimistic scenario, there are no vacancy and collection losses and operating expenses and capital expenditures consume 40 percent and three percent, respectively, of expected gross income each year. The going-out cap rate is assumed to increase three basis points per year. A 10-year holding period assumption is used in both scenarios.

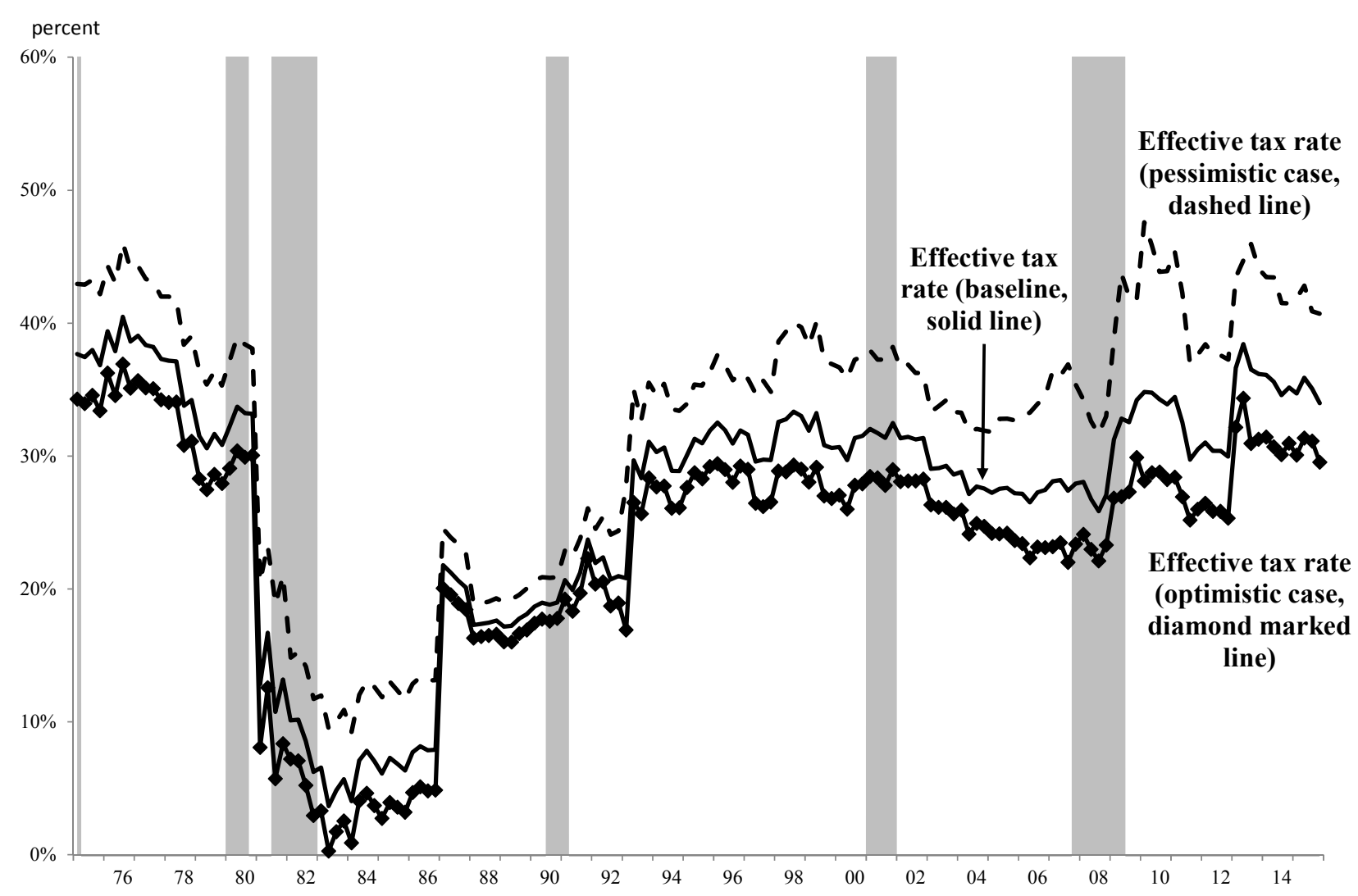

Shaded areas denote recessions. Sources: authors' calculations. 


\section{Figure 10: How tax-adjusted fundamentals mainly drive cap rates}

Data on quarterly cap rates are from the American Council of Life Insurers (ACLI) Commercial Mortgage Commitments - Historical Database. Based on estimates from Duca and Ling (2015), investors' required rate of return ( $r$ ) equals the 10-year Treasury yield plus a risk premium, estimated to equal the sum of a constant (1.92), a general risk premium (0.814 times the spread between Baarated corporate and 10-yr. Treasury yields), and the effective bank capital requirement on CRE ( $0.27 \mathrm{x}$ effective capital requirement). The growth rate (g) of nominal rents is proxied by the expected average annual inflation rate over the next 10 years from the Federal Reserve Board's quarterly model of the U.S. economy. (1-taxdep) uses our 10-year holding period calculation of the present value of tax depreciation. After the Federal Reserve lowered inflation in the early 1980s, office cap rates have generally moved in line with $(r-g)(1-t a x d e p)$.

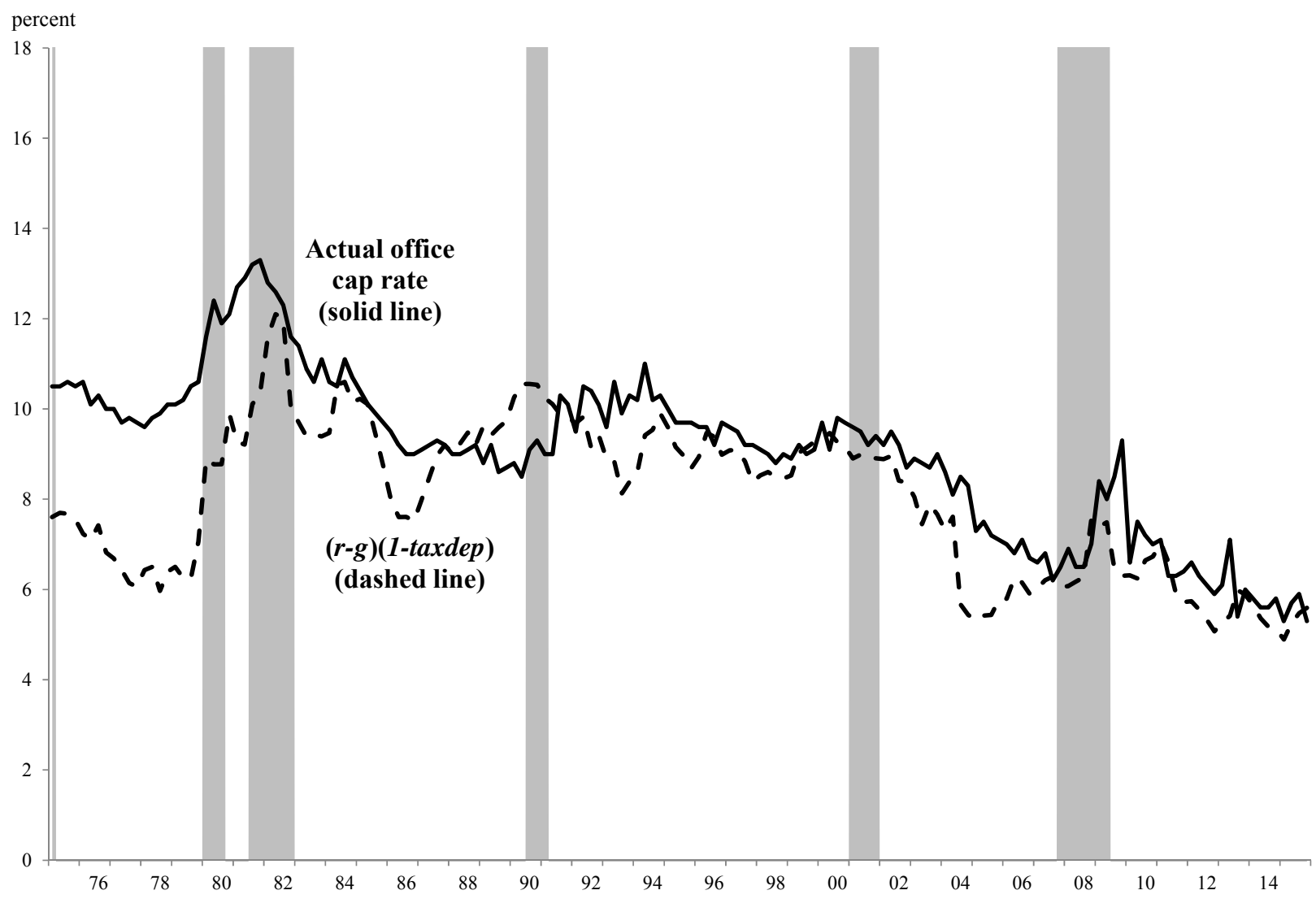

Shaded areas denote recessions. Sources: ACLI, Federal Reserve Board, and authors' calculations. 
Figure 11: Estimated equilibrium cap rate tracks office cap rates since the 1970s

Capitalization rates are from the American Council of Life Insurers (ACLI) Commercial Mortgage Commitments-Historical Database. The equilibrium office cap rates are the long-run estimated equilibrium cap rate from models 1 and 2 in Table 2 . The former is given by CapRate $=-0.372+1.021$ $(r-g)+4.465$ InflatEra, and the latter is given by CapRate $=0.864+0.983(r-g)(1-$ taxdep $)+1.999$ InflatEra $(1-$ taxdep), where $\mathrm{r}$ is the proxy for the required rate of return on CRE office investments from Duca and Ling (2015), $\mathrm{g}$ is the 10-year expected future inflation rate from the Federal Reserve Board's econometric model of the U.S. economy, InflatEra is a shift dummy to account for risk premia associated with uncertainty before the post-1981 era of low inflation equal to 1 before 1982Q1 and 0 since then, and taxdep is our estimate of the present value of net depreciation tax benefits.

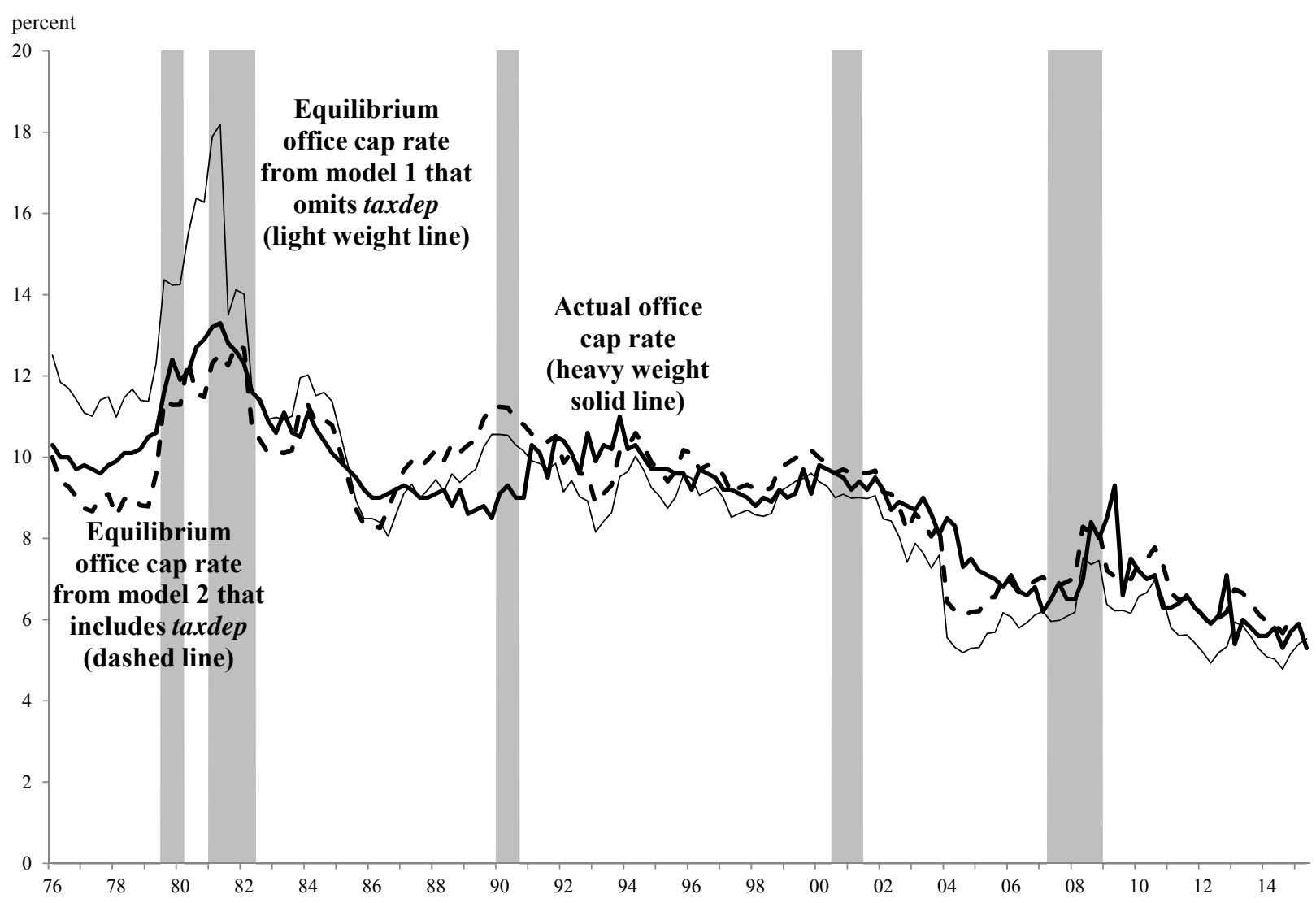

Shaded areas denote recessions. Sources: ACLI, Federal Reserve Board, and authors' calculations. 


\section{Table 1: Depreciation Methods and Tax Rates}

Panel A: 1975-1987

\begin{tabular}{|c|c|c|c|c|c|c|c|}
\hline & $1975-1978$ & 1979-1980 & $\begin{array}{c}\text { ERTA } \\
1981 \\
\end{array}$ & $\begin{array}{c}1982^{-} \\
1984 \mathrm{Q} 1 \\
\end{array}$ & $\begin{array}{l}\text { 1984Q2- } \\
\text { 1985Q1 }\end{array}$ & $\begin{array}{c}1985 Q^{-} \\
1986\end{array}$ & $\begin{array}{l}\text { TRA } \\
1987 \\
\end{array}$ \\
\hline $\begin{array}{l}\text { Allowable method of } \\
\text { depreciation: used } \\
\text { residential }\end{array}$ & $\begin{array}{c}125 \% \\
\text { declining } \\
\text { balance }^{\mathrm{a}}\end{array}$ & $\begin{array}{c}125 \% \\
\text { declining } \\
\text { balance }^{\mathrm{a}}\end{array}$ & $\begin{array}{c}175 \% \\
\text { declining } \\
\text { balance }\end{array}$ & $\begin{array}{c}175 \% \\
\text { declining } \\
\text { balance }\end{array}$ & $\begin{array}{c}175 \% \\
\text { declining } \\
\text { balance }\end{array}$ & $\begin{array}{c}175 \% \\
\text { declining } \\
\text { balance }\end{array}$ & $\begin{array}{l}\text { Straight- } \\
\text { line }\end{array}$ \\
\hline $\begin{array}{l}\text { Allowable method of } \\
\text { depreciation: used non- } \\
\text { residential }\end{array}$ & Straight-line $^{b}$ & Straight-line ${ }^{b}$ & $\begin{array}{c}175 \% \\
\text { declining } \\
\text { balance }\end{array}$ & $\begin{array}{c}175 \% \\
\text { declining } \\
\text { balance }\end{array}$ & $\begin{array}{c}175 \% \\
\text { declining } \\
\text { balance }\end{array}$ & $\begin{array}{c}175 \% \\
\text { declining } \\
\text { balance }\end{array}$ & $\begin{array}{l}\text { Straight- } \\
\text { line }\end{array}$ \\
\hline $\begin{array}{l}\text { Cost recovery period: } \\
\text { used residential }\end{array}$ & About 30 yrs. & About 30 yrs. & 15 yrs. & 15 yrs. $^{c}$ & $18 \mathrm{yrs}^{\mathrm{c}}$ & 19 yrs. $^{\mathrm{d}}$ & 27.5 yrs. \\
\hline $\begin{array}{l}\text { Cost recovery period: } \\
\text { used non-residential }\end{array}$ & About 30 yrs. & About 30 yrs. & 15 yrs. & 15 yrs. $^{c}$ & $18 \mathrm{yrs}^{\mathrm{c}}$ & $19 \mathrm{yrs}^{\mathrm{d}}$ & 31.5 yrs. \\
\hline 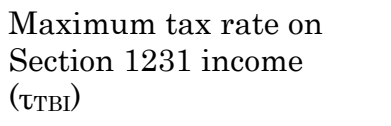 & $70 \%$ & $70 \%$ & $70 \%$ & $50 \%$ & $50 \%$ & $50 \%$ & $38.5 \%$ \\
\hline $\begin{array}{l}\text { Maximum tax rate on } \\
\text { capital gain income }\left(\tau_{\mathrm{CG}}\right)\end{array}$ & $33.9 \%-39.9 \% \mathrm{e}^{\mathrm{e}}$ & $28 \%$ & $20 \%$ & $20 \%$ & $20 \%$ & $20 \%$ & $28 \%$ \\
\hline $\begin{array}{l}\text { Maximum tax rate on } \\
\text { straight-line depreciation } \\
\text { recapture income }\left(\tau_{S L R}\right)\end{array}$ & $33.9 \%-39.9 \% \mathrm{e}^{\mathrm{e}}$ & $28 \%$ & $20 \%$ & $20 \%$ & $20 \%$ & $20 \%$ & $28 \%$ \\
\hline 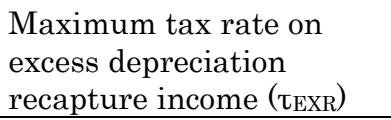 & $70 \%$ & $70 \%$ & $70 \%$ & $50 \%$ & $50 \%$ & $50 \%$ & NA \\
\hline
\end{tabular}

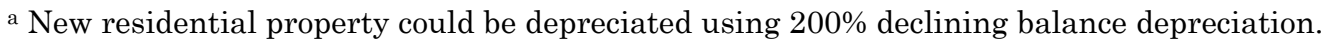

${ }^{\mathrm{b}}$ New nonresidential property could be depreciated using $150 \%$ declining balance depreciation.

c For property placed in service after March 15, 1984 and before May 9, 1985, the Tax Reform Act of 1984

generally increased the minimum cost recovery period for both residential and non-residential real property from 15 to 18 years.

d For property placed in service after May 8, 1985 and before 1987, the minimum cost recovery period for residential and non-residential real property was 19 years.

e See discussion in text for details. 
Table 1: Depreciation Methods and Tax Rates, continued

\begin{tabular}{|c|c|c|c|c|c|c|c|}
\hline & 1988-1990 & 1991-1992 & $\begin{array}{l}1993^{-} \\
1996^{\mathrm{e}}\end{array}$ & 1997 & 1998-2003Q1 & $\begin{array}{c}2003 \mathrm{Q} 2^{-} \\
2012\end{array}$ & $\begin{array}{c}2013^{-} \\
2015 \mathrm{Q} 2\end{array}$ \\
\hline $\begin{array}{l}\text { Allowable method of } \\
\text { depreciation: used } \\
\text { residential }\end{array}$ & $\begin{array}{l}\text { Straight- } \\
\text { line }\end{array}$ & $\begin{array}{l}\text { Straight- } \\
\text { line }\end{array}$ & $\begin{array}{l}\text { Straight- } \\
\text { line }\end{array}$ & $\begin{array}{l}\text { Straight- } \\
\text { line }\end{array}$ & Straight-line & $\begin{array}{l}\text { Straight- } \\
\text { line }\end{array}$ & $\begin{array}{l}\text { Straight- } \\
\quad \text { line }\end{array}$ \\
\hline $\begin{array}{l}\text { Allowable method of } \\
\text { depreciation: used non- } \\
\text { residential }\end{array}$ & $\begin{array}{l}\text { Straight- } \\
\text { line }\end{array}$ & $\begin{array}{l}\text { Straight- } \\
\text { line }\end{array}$ & $\begin{array}{l}\text { Straight- } \\
\text { line }\end{array}$ & $\begin{array}{l}\text { Straight- } \\
\text { line }\end{array}$ & Straight-line & $\begin{array}{l}\text { Straight- } \\
\text { line }\end{array}$ & $\begin{array}{l}\text { Straight- } \\
\text { line }\end{array}$ \\
\hline $\begin{array}{l}\text { Cost recovery period: } \\
\text { used residential }\end{array}$ & 27.5 yrs. & 27.5 yrs. & 27.5 yrs. & 27.5 yrs. & 27.5 yrs. & 27.5 yrs. & 27.5 yrs. \\
\hline $\begin{array}{l}\text { Cost recovery period: } \\
\text { used non-residential }\end{array}$ & 31.5 yrs. & 31.5 yrs. & 39 yrs. & 39 yrs. & 39 yrs. & 39 yrs. & 39 yrs. \\
\hline $\begin{array}{l}\text { Maximum tax rate on } \\
\text { capital gain income }\left(\tau_{\mathrm{CG}}\right)\end{array}$ & $28 \%$ & $28 \%$ & $28 \%$ & $20 \%$ & $20 \%$ & $15 \%$ & $23.8 \%$ \\
\hline $\begin{array}{l}\text { Maximum tax rate on } \\
\text { straight-line depreciation } \\
\left.\text { recapture income ( } \tau_{\text {SLR }}\right)\end{array}$ & $28 \%$ & $28 \%$ & $28 \%$ & $20 \%$ & $25 \%$ & $25 \%$ & $28.8 \%$ \\
\hline $\begin{array}{l}\text { Maximum tax rate on } \\
\text { excess depreciation } \\
\left.\text { recapture income ( }{ }_{\text {EXXR }}\right)\end{array}$ & NA & NA & NA & NA & NA & NA & NA \\
\hline
\end{tabular}

e The Tax Reform Act of 1986 required 27.5 year straight-line depreciation for acquisitions of both new and used residential property and 31.5 year straight-line for nonresidential property. This tax treatment remained in effect until May 12, 1993. As a result of the Omnibus Budget Reconciliation Act of 1993, the cost recovery period for non-residential real property placed in service after May 13, 1993 is 39 years. 
Table 2: Explanation of Capitalization Rates on Commercial Office Property

\begin{tabular}{|c|c|c|c|c|c|c|c|}
\hline \multirow{3}{*}{$\begin{array}{l}\text { Equilibrium CapRate }_{\text {t }} \\
\text { Variables/Sample } \\
\text { Model No. }\end{array}$} & \multirow{2}{*}{\multicolumn{4}{|c|}{$\begin{array}{c}=\alpha_{0}+\alpha_{1}\left(n-g_{t}\right)\left(1-t_{\text {taxdep }}\right)+\alpha_{2}[\text { Inflath } \\
\text { Full: } 1976: \mathrm{Q} 3-2015: \mathrm{Q} 4\end{array}$}} & \multirow{2}{*}{\multicolumn{3}{|c|}{$\begin{array}{l}\left.\left.\operatorname{taxde}_{\mathrm{t}}\right)\right]+\mu_{\mathrm{t}} \\
\text { Post-TRA86: 88:Q1-15:Q4 }\end{array}$}} \\
\hline & & & & & & & \\
\hline & 1 & 2 & 3 & 4 & 5 & 6 & 7 \\
\hline & \multicolumn{7}{|c|}{ Inter-action variables (tax horizons) } \\
\hline Tax Treatment & unity & $\begin{array}{c}10 \text { year } \\
(1-\text { taxdep })\end{array}$ & $\begin{array}{c}6 \text { year } \\
1-\text { taxdep })\end{array}$ & $\begin{array}{l}14 \text { year } \\
(1-\text { taxdep })\end{array}$ & unity & $\begin{array}{c}10 \text { year } \\
(1-\text { taxdep })\end{array}$ & $\begin{array}{c}14 \text { year } \\
(1-\text { taxdep })\end{array}$ \\
\hline Constant & 0.372 & 0.864 & 1.066 & 0.620 & -0.183 & 0.444 & 0.425 \\
\hline$\left(r_{\mathrm{t}}-g_{\mathrm{t}}\right)$ & $\begin{array}{l}1.021^{* *} \\
(0.107)\end{array}$ & $\begin{array}{l}0.983^{* *} \\
(0.087)\end{array}$ & $\begin{array}{l}0.932^{* *} \\
(0.079)\end{array}$ & $\begin{array}{l}1.038^{* *} \\
(0.098)\end{array}$ & $\begin{array}{l}1.060^{* * *} \\
(0.119)\end{array}$ & $\begin{array}{l}1.008^{* *} \\
(0.107)\end{array}$ & $\begin{array}{l}1.023^{* *} \\
(0.108)\end{array}$ \\
\hline InflatErat & $\begin{array}{l}4.645^{* *} \\
(0.869)\end{array}$ & $\begin{array}{l}1.999^{* *} \\
(0.621)\end{array}$ & $\begin{array}{l}2.076^{* *} \\
(0.576)\end{array}$ & $\begin{array}{l}2.066^{* *} \\
(0.702)\end{array}$ & & & \\
\hline $\begin{array}{l}\text { unique cointegrating } \\
\text { trace/max eigen }\end{array}$ & Yes ${ }^{*} /$Yes$^{*}$ & Yes $^{*}$ Yes $^{*}$ & Yes ${ }^{*}$ Yes $^{*}$ & Yes $^{*}$ Yes $^{*}$ & Yes $^{*}$ Yes $^{*}$ & * Yes ${ }^{*}$ Yes $^{*}$ & Yes $^{*}$ Yes $^{*}$ \\
\hline \# lags in vector & 3 & 5 & 5 & 5 & 2 & 5 & 5 \\
\hline trace, no vector & $31.80^{*}$ & $31.46^{*}$ & $31.23^{*}$ & $30.71^{*}$ & $15.87^{*}$ & $16.15^{*}$ & $16.32^{*}$ \\
\hline trace, 1 vector & 8.41 & 8.26 & 10.66 & 6.43 & 0.35 & 3.84 & 0.09 \\
\hline \multicolumn{8}{|c|}{$\begin{aligned} \text { Short-Run: } \Delta \text { CapRate }= & B_{0}+B_{1} E C_{t-1}+\Sigma B_{2 i} \Delta \text { CapRate }_{t-\mathrm{i}}+\Sigma B_{3 \mathrm{i}} \Delta\left[\left(\boldsymbol{n}-g_{\mathrm{t}}\right)\left(1-\text { taxdep }_{\mathrm{t}-\mathrm{i}}\right)\right. \\
& +\Sigma B_{4 \mathrm{i}} \Delta\left[\text { InflatErat } \mathrm{i}\left(1-\text { taxdep }_{\mathrm{t}-\mathrm{i}}\right)\right]+\mathrm{X}_{\mathrm{t}}+\varepsilon_{\mathrm{t}}\end{aligned}$} \\
\hline $\begin{array}{l}E C_{\mathrm{t}-1} \\
\text { 'adjustment speed' }\end{array}$ & $\begin{array}{l}-0.037 \\
(0.033)\end{array}$ & $\begin{array}{l}-0.195^{* *} \\
(0.050)\end{array}$ & $\begin{array}{l}-0.211^{* *} \\
(0.055)\end{array}$ & $\begin{array}{l}-0.172^{* *} \\
(0.045)\end{array}$ & $\begin{array}{l}-0.175^{* *} \\
(0.050)\end{array}$ & $\begin{array}{l}-0.234^{* *} \\
(0.061)\end{array}$ & $\begin{array}{l}-0.232^{* *} \\
(0.060)\end{array}$ \\
\hline$\Delta$ CapRate $\mathrm{t}-1$ & $\begin{array}{l}-0.521^{* *} \\
(0.080)\end{array}$ & $\begin{array}{l}-0.415^{* *} \\
(0.080)\end{array}$ & $\begin{array}{l}-0.406^{* *} \\
(0.083)\end{array}$ & $\begin{array}{c}-0.423^{* *} \\
(0.079)\end{array}$ & $\begin{array}{l}-0.525 \\
(0.085)\end{array}$ & $\begin{array}{l}-0.391^{* *} \\
(0.094)\end{array}$ & $\begin{array}{l}-0.393^{* *} \\
(0.094)\end{array}$ \\
\hline$\Delta\left[\left(r^{-}-g_{\mathrm{t}}\right)(1-\operatorname{tax} d e p)\right]_{\mathrm{t}-1}$ & $\begin{array}{l}-0.053 \\
(0.077)\end{array}$ & $\begin{array}{r}-0.135 \\
(0.089)\end{array}$ & $\begin{array}{l}-0.124 \\
(0.089)\end{array}$ & $\begin{array}{l}-0.139 \\
(0.088)\end{array}$ & $\begin{array}{r}0.178 \\
(0.117)\end{array}$ & $\begin{array}{c}0.244 \\
(0.127)\end{array}$ & $\begin{array}{r}0.249 \\
(0.128)\end{array}$ \\
\hline$\Delta[\operatorname{InflatEra}(1-\operatorname{tax} d e p)]_{\mathrm{t}-1}$ & $\begin{array}{c}0.484 \\
(0.409)\end{array}$ & $\begin{array}{c}0.220 \\
(0.539)\end{array}$ & $\begin{array}{r}0.211 \\
(0.471)\end{array}$ & $\begin{array}{c}0.242 \\
(0.619)\end{array}$ & & & \\
\hline CreditControlt & $\begin{array}{l}0.912^{* *} \\
(0.302)\end{array}$ & $\begin{array}{l}1.156^{* *} \\
(0.296)\end{array}$ & $\begin{array}{l}1.152^{* *} \\
(0.296)\end{array}$ & $\begin{array}{l}1.148^{* *} \\
(0.297)\end{array}$ & & & \\
\hline $\operatorname{Reg} Q_{t 1}$ & $\begin{array}{l}0.101 \\
(0.70)\end{array}$ & $\begin{array}{c}0.290^{* *} \\
(0.065)\end{array}$ & $\begin{array}{l}0.246^{* *} \\
(0.062)\end{array}$ & $\begin{array}{l}0.309^{* * *} \\
(0.067)\end{array}$ & & & \\
\hline $\operatorname{Lehman}_{\mathrm{t}}$ & $\begin{array}{l}1.676^{* *} \\
(0.405)\end{array}$ & $\begin{array}{l}1.614^{* * *} \\
(0.391)\end{array}$ & $\begin{array}{l}1.583^{* *} \\
(0.392)\end{array}$ & $\begin{array}{l}1.648^{* * *} \\
(0.392)\end{array}$ & $\begin{array}{l}1.784^{* * *} \\
(0.406)\end{array}$ & $\begin{array}{l}1.724^{* * *} \\
(0.436)\end{array}$ & $\begin{array}{c}1.727^{* *} \\
(0.436)\end{array}$ \\
\hline Adj. $R^{2}$ & 0.356 & 0.422 & 0.418 & 0.414 & 0.400 & 0.432 & 0.433 \\
\hline S.E. & 0.388 & 0.367 & 0.368 & 0.370 & 0.409 & 0.398 & 0.398 \\
\hline VEC Auto (1) & 8.29 & 9.42 & 8.89 & 10.77 & 4.33 & 4.65 & 4.33 \\
\hline VEC Auto (2) & $23.95^{* *}$ & 15.92 & 19.51 & 13.15 & 4.10 & 7.69 & 7.11 \\
\hline VEC Auto (4) & 10.29 & 7.93 & 9.37 & 8.52 & 6.47 & 7.22 & 7.11 \\
\hline VEC Auto (6) & 10.43 & 4.06 & 4.06 & 4.71 & 0.54 & 1.23 & 1.28 \\
\hline
\end{tabular}


Notes: (i) Standard errors in parentheses. ${ }^{* *}\left(^{*}\right)$ denotes significant at the $99 \%$ (95\%) confidence level. (ii) Lag lengths chosen to based on minimizing the AIC. (iii) First difference terms of elements in the cointegrating vector lagged more than one quarter and the constant in the short-run models are omitted to conserve space. (iv) Maximum likelihood estimates of the equilibrium relationship using a threeequation system with (at most) one cointegrating vector. Our cointegrating system is interpretable as a two-variable system with a parameter change. That said, because (1-taxdep) varies some in the early sample, the interactive variable InFlatEra (1-taxdep) is treated as a long-run variable in the estimation. Note that the estimates of the long-run coefficient on the main driver of caprates, $\left(r^{-} g\right)$ were similar in post-1987 samples that omit the parameter shift variable, when the system is a two-variable cointegrating system. (v) The VEC auto (LM) statistics are systems Lagrange Multiplier tests statistics for $1^{\text {st }}$ through $6^{\text {th }}$ order autocorrelation. (vi) $\operatorname{Reg} Q$ controls for Regulation $\mathrm{Q}$ induced credit rationing by tracking the extent to which market interest rates exceeded effective deposit interest rate ceilings. CreditControl equals 1 in $1980 \mathrm{Q} 1$ and 1980Q2 (0 otherwise) to control for credit rationing from government credit controls that depressed cap rates. Lehman is a dummy for Lehman's failure (= 1 in 2009Q1 in the office models and = 1 in 2008Q4 in the multi-family models) and ContIllFail is a dummy for the failure of Continental Illinois Bank (= 1 in 1984Q3). 
Table 3: Explanation of Capitalization Rates on Commercial Multi-Family Property

Equilibrium CapRate $_{t}=\alpha_{0}+\alpha_{1}\left(r_{t}-g_{t}\right)\left(1-\right.$ taxdep $\left._{t}\right)+\alpha_{2}\left[\right.$ InflatEra $t\left(1-\right.$ taxdep $\left.\left._{t}\right)\right]+\mu_{t}$

Variables/Sample

Model No.

Full: 1976:Q2-2015:Q4

Post-TRA86: 88:Q1-15:Q4

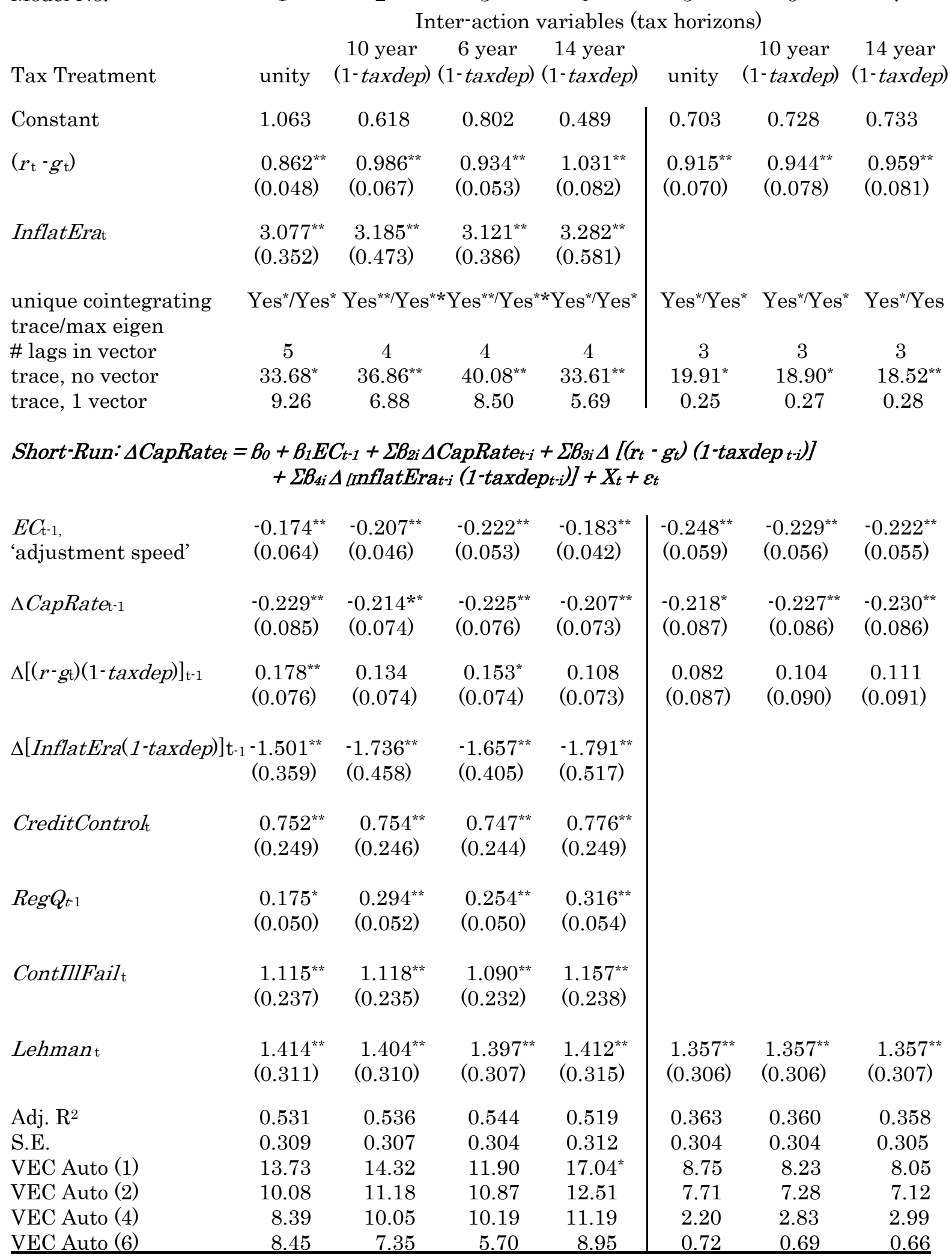


Notes: (i) Standard errors in parentheses. ${ }^{* *}\left(^{*}\right)$ denotes significant at the $99 \%$ (95\%) confidence level. (ii) Lag lengths chosen to based on minimizing the AIC. (iii) First difference terms of elements in the cointegrating vector lagged more than one quarter and the constant in the short-run models are omitted to conserve space. (iv) Maximum likelihood estimates of the equilibrium relationship using a threeequation system with (at most) one cointegrating vector. Our cointegrating system is interpretable as a two-variable system with a parameter change. That said, because (1-taxdep) varies some in the early sample, the interactive variable InFlatEra (1-taxdep) is treated as a long-run variable in the estimation. Note that the estimates of the long-run coefficient on the main driver of caprates, $\left(r^{-} g\right)$ were similar in post-1987 samples that omit the parameter shift variable, when the system is a two-variable cointegrating system. (v) The VEC auto (LM) statistics are systems Lagrange Multiplier tests statistics for $1^{\text {st }}$ through $6^{\text {th }}$ order autocorrelation. (vi) $\operatorname{Reg} Q$ controls for Regulation $\mathrm{Q}$ induced credit rationing by tracking the extent to which market interest rates exceeded effective deposit interest rate ceilings. CreditControl equals 1 in $1980 \mathrm{Q} 1$ and 1980Q2 (0 otherwise) to control for credit rationing from government credit controls that depressed cap rates. Lehman is a dummy for Lehman's failure (= 1 in 2009Q1 in the office models and = 1 in 2008Q4 in the multi-family models) and ContIllFail is a dummy for the failure of Continental Illinois Bank (= 1 in 1984Q3). 